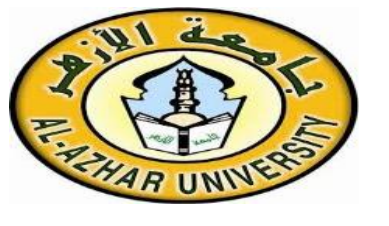

$$
\begin{aligned}
& \text { جامعة الأزهر } \\
& \text { كلية اللدراسات الإسلامية والعربية } \\
& \text { للبنين بالديدامون - شر قية }
\end{aligned}
$$

\title{
نظام الإرث في الإسلام وأبعاده الوسطية
}

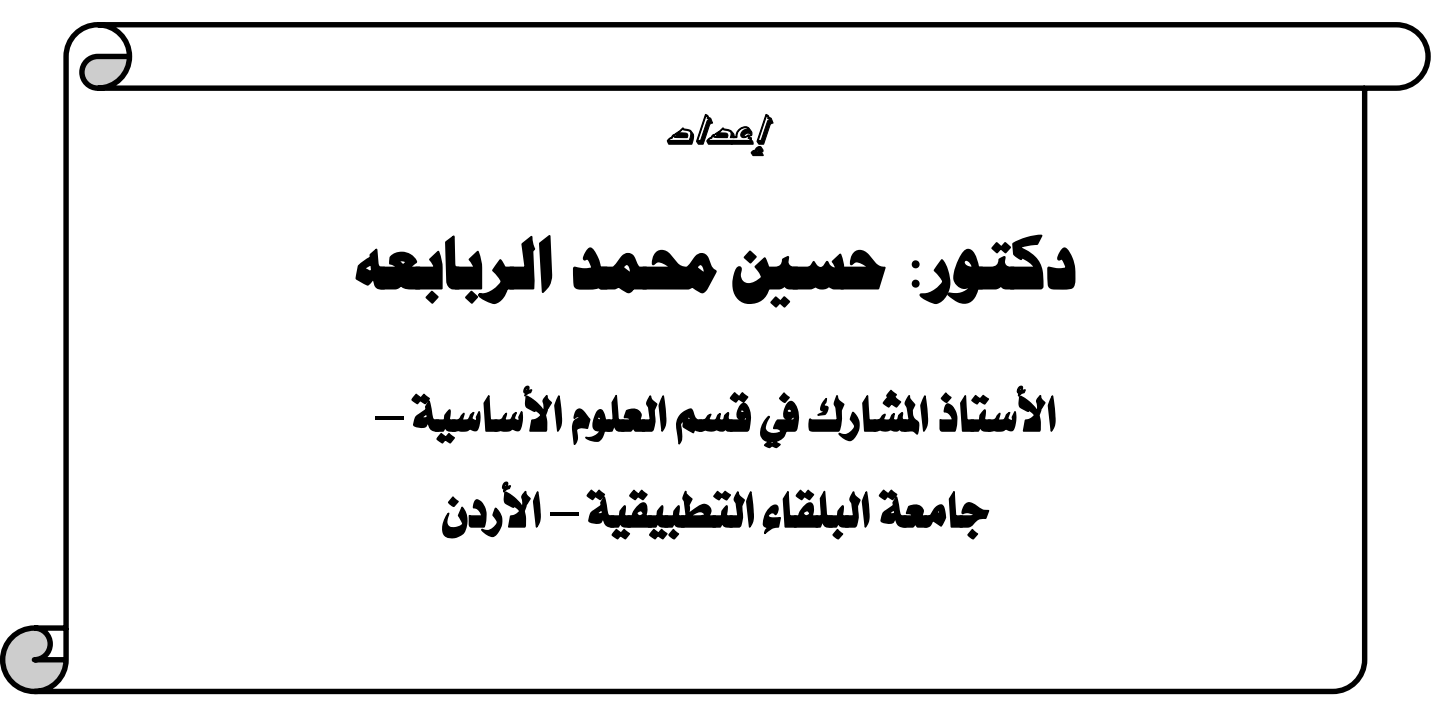

$$
\text { المؤتمر العلمي الدولي الأول }
$$

$$
\text { rer }
$$


$-1 \cdot \leqslant \Lambda$. 


\section{نظام الإرث فِ الإسلاموأبعاده الوسطية}

حسين محمدل الريابعه

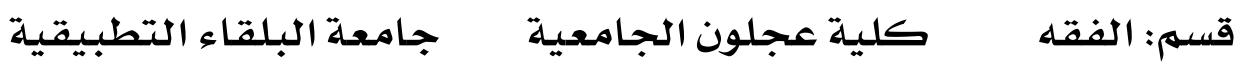
المدينة: الأردن الدونة: الأردن

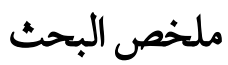

وضـعت الشر-يعة الاسـلامية نظام المواريث على أحسـن النظم المالية وأحكمها وأعدلها ، فقررت ملكية الإنســان للمال ذكرا كان أم انثى بالطرق الشر-عية ، فالمال الذي يتركه المثوفن يتتقل بعدالة

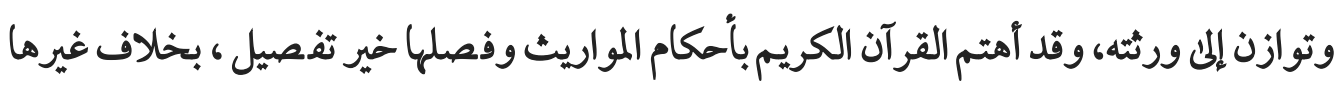
من الأمكام التي جاءت فيه مجملة وفصلتها السنة النبوية . وقد جاء مذا النظام متصفا بالوسطية بين غيره من الأنظمة المتطرفة منعا من الميراث بالكلية أو فتح

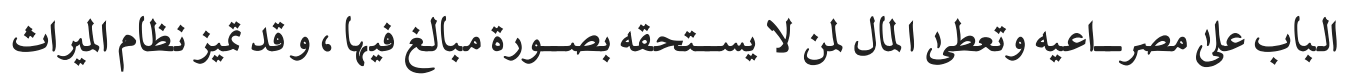

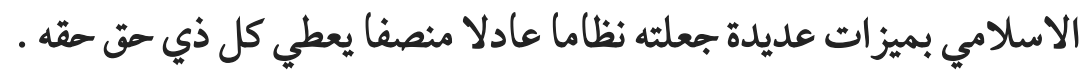
وهذا البحث يعالج مشكلة يقع فيها كثير من الناس بالابتعادعن تطبيق أحكام اللهفي الميراث واتباع

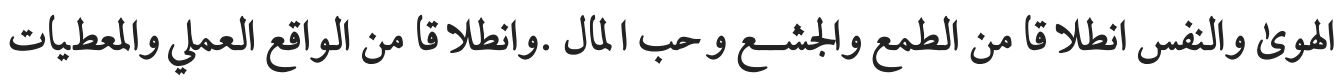

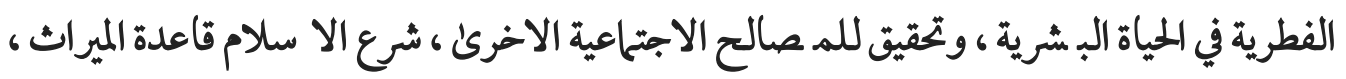

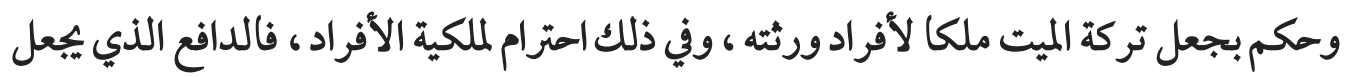

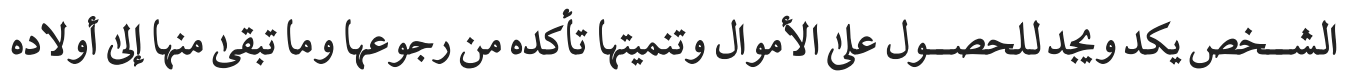
وذوي أقربائه الذين يعتبرهم امتدادًا لوجوده وحياته من بعده كلمات المفتاحية: الإرث - الإسلام - الوسطية - العدالة 
The inheritance system in Islam and its dimensions moderation

Hussein Mohammed Al-Rababah

Department of jurisprudence

The Ministry of Awqaf and Religious Affairs

city: Kurdistan

Country: Republic of Iraq

Abstract:

Islamic law put the system of inheritance on the best, wisest and fairest financial system, so it decided the ownership of money by humans, whether male or female, through legal means, the money left by the deceased is transferred in justice and balance to his heirs, and the Holy Qur'an has collected other rulings on inheritance and separated them in the best detail, unlike the rulings that include a summary, Summarized and separated by the Sunnah.

This system was characterized by moderation among other extremist systems, to prevent inheritance altogether or open the door wide and give money to those who do not deserve it in an exaggerated manner.

This research deals with a problem in which many people fall away from applying the provisions of God in inheritance and following whims and self, out of greed, and love of money. And based on the practical reality and the innate data in human life, and the achievement of other social interests, Islam legislated the rule of inheritance, and the rule of making the legacy of the dead It is owned by the members of his heirs, and this is respect for the property of individuals. The motive that makes a person toil and finds to obtain and develop money makes sure that he returns it and what remains of it to his offspring and relatives, whom he considers an extension of his existence and his life after him.

Key word: inheritance- Islam - moderation- Justice

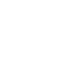




\section{وسطية نظام الميراث الإسلامي ومدالته}

\section{المقلدمة}

و ضعت الشريعة الإ سلامية نظام المواريث على أهسن النظم المالية وأحكمها وأعدلها، فقررت ملكية الإنسان للمال ذكرا كان أم أنثى بالطرق الشرعية، فانتقال ملكية ما يتركه المورث من أمواله

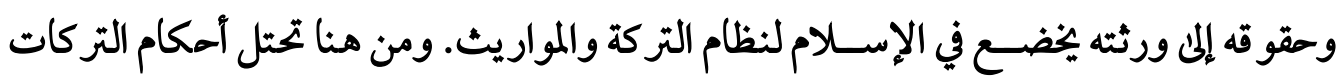

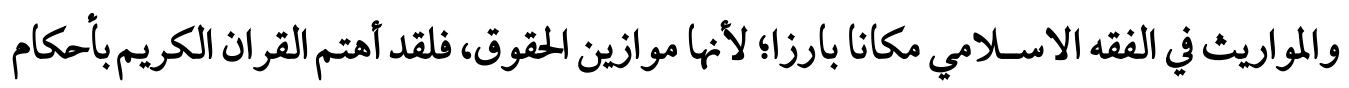
المواريث، فلم تحظى به أي ناحية أخرئ من نواحي التشريع باعتباره علم) متعلقا بآخر حياة الإنسان. أهمية البحث الميراث والتر كة على در جة كبيرة من الأمية في هياة الناس ، لما فيها من توزيع أموال المتوفن على

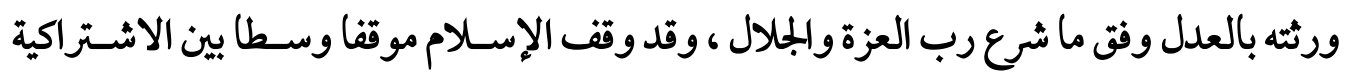

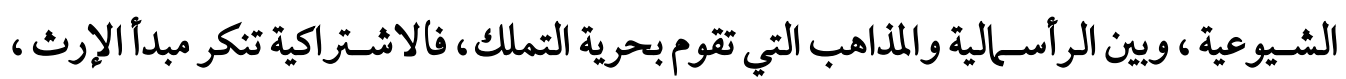

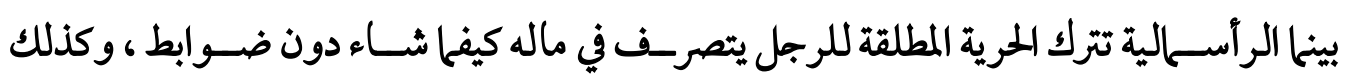

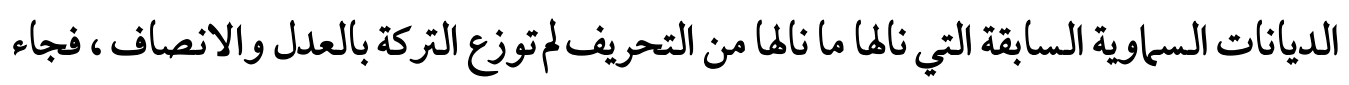

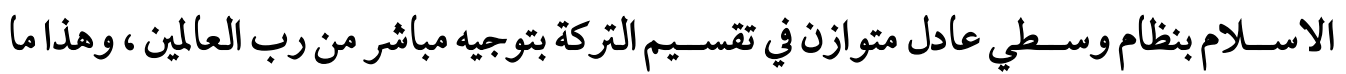
يوضحه هذا البحث . أهداف البحث

يهدف مذا البحث لتحقيق الأهداف الرئيسية التالية : 1- ايضاح الجور في توزيع التركة بين الورثة في الانظمة المختلفة .

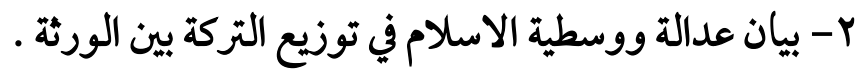
ب- الحث علني الالتزام والتمسك بأحكام الله فيا يتعلق بالميراث ع- إظهار تميز الإسلام في توزيع التركة على ما عداه من أنظمة .

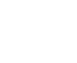


تتمثل مشكلة البحث في ابتعاد كثير من الناس عن آحكام الشريعة فيلا يتعلق بالميراث ، انطلاقا من الطمع والجشع وحب المال ، وتطرف بعض الأنظمة الجاملية والمعاصرة في توزيع التركة والبعدعن العدالة في توزيعها بين الورثة بالقسـطاس المسـتقيم، وتأتي هذه الدراسـة لتجلي صــورة الإسـلام الناصعة في توزيع التركة بين الورثة بمنهج وسطي عادل . منهجية البحث سيتم اتباع المنهج الا ستقرائي والو صفي في إعداد هذا البحث لبيان أحكام الشُريعة الإ سلامية في تقسـيم التر كة و عدالتها ، والاطلاع على الآيات القرآنية الواردة في هذا المجال والوقوف على تفسـيرها ، والاطلاع علنى الاحاديث النبوية التي تناولت أحمام المواريث ـ ـ والرجوع المى أمهات الكتب الفقهية والمراجع التي وضـعت في علم المواريث ، والاطلاع على الأبحاث العلمية المحكمة التي تناولت هذا الجانب ، والموازنة بين أحكام الإسلام والأنظمة والتشريعات الأخرى وتم تقسيم البحث إلى مقدمة وأربعة مباحث وخاتمة.

المقدمة المبحث الاول : تعريف الميراث وأدلة مشروعيته المبحث الثاني : اهمية نظام المواريث ومكانته في المبحث الثالث : ميزات نظام الميراث الاسلامي المبحث الرابع : وسطية نظام في الاسلام وعدالته 


\section{المبعث الاول}

\section{تصريف الميراث وأدلة مشروميته}

الميراث في اللغة: مصدر لفعل ورث، يرث، ارثا وميراثا، ومعناه انتقال الشيء من شخص لآخر. أما الميراث في الاصــلاح الفقهي: فهو أســملما يسـتحقه الوارث من مورثه بسـبب من أسـباب الإرث، ســواء كان المتروك مالا آو عقارا آو من الحقوق الشرـعية، فهو علم يعرف بمقتضــاه نوع المستحقين للتركة ونصيب كل وارث وهو علم ما بعد الموت . اما المقصود بعلم الميراث فهو القواعد الفقهية والحسابية التي يعرف بها حق أو نصيب كل وارث من التركة. والمواريث والفرائض تأتي بمعنى واحد ومصطلحات لمسمى واحد وهو الملال الذي يتركه الميت . تعريف الفرائض : الفرايض جمع فريضة مأخوذة من الفرض وله في اللغة معان عديدة منها :

اللز ومنه فرض القوس وهو الحز الذي في طرفه حيث يوضع الوتر (') القطع يقال :فرضت لفلان كذا من المال اي قطعت له شيئا منه . التقدير ومنه قوله تعاله : ( فنصف ما فرضتم ) (r) الانزال ومنه قوله تعاله : ( ان الذي فرض عليك القران لرادك المي معاد ) (r) التبين ومنه قوله تعاله : ( قد فرض الله لكم تحلة أيهانكم ) (ء) الاحلال ومنه قوله تعالى: ( ما كان على النبي من حرج فيا فرض اللهله ) (·)

( ) فتح الباري ص r ج r ا ط السلفية r r سورة البقرة الآية rrV r ) سورة القصص الآية 10

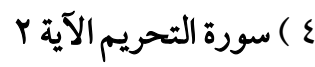

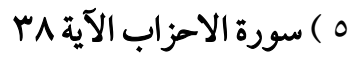


وتطلق الفريضة لغة ايضا على ما فرض في السائمة من الصدقة وعلى المرمة وعلى الحصة المفروضة ( ) وعلم الفرانض قيل هو فقه المواريث وما ضم اليه من حسابها (r) وهذا تعريف له بالمعنى المصدري وفيه اجمال والمطلوب في التعريف آن يكون حاويا لتفاصـيل المعرف وقيل هو علم يعرف به كيفية قسمة التركة على مستحقيها (r)

$$
\text { وقيل هو علم يعرف به من يرث ومن لا يرث ومقدار ما لكل وارث ( ) }
$$

وسميت مسائل هذا الفن بالفرائض مع أن فيها مسائل تعصيب وسمي الكل فرائض وجعل لقبا لهذا الفن (') وأصل هذه التسمية مأخوذة من قوله تعالى : (نصيبا مفروضا ) (ن) آو مقدرا أو معلوما آو مقطوعا عن غيره (v) وبهذا يظهر مطابقة التعريف الاصطلاحي للتعريف اللغوي ، وآن المعنى اللغوي أعم من المعنى الاصطلاحي. حكمة مشروعية الميراث انطلاقا من الواقع العملي والمعطيات الفطرية في الحياة البشرية ، وتحقيق للمصــالح الاجتحاعية الأخرى ، شرع الإسـلام قاعدة الميراث ، وحكم بجعل تركة الميت ملكا لأفراد ورثته ، وفي ذلك

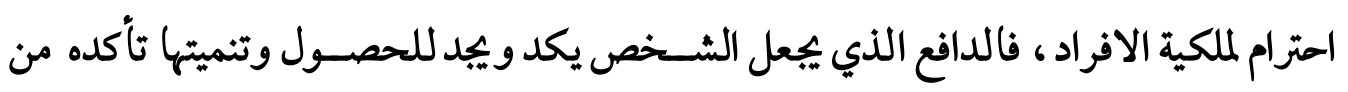
رجوعها وما تبقى منها المه اولاده وذوي آقربائه الذين يعتبرهم امتدادا لوجوده وحياته من بعده . أدلة مشروعية المواريث

$$
\begin{aligned}
& \text { ( ) القاموس المحيط ص • ع Y ج Y ط السعادة بمصر }
\end{aligned}
$$

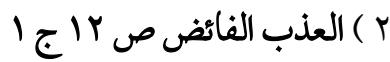

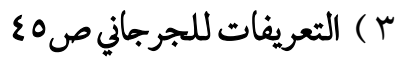

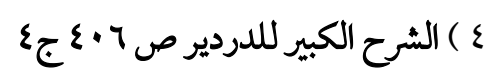

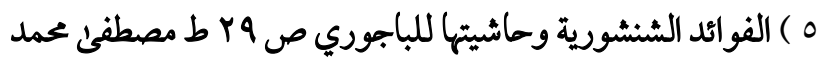
T ) سورة النساء الآية

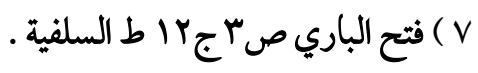


وردت المواريث في آيات القران الكريم فقدجاءت في سورة النساء ثلاث آيات : الاولى ( 11 من سـورة النسـاء) في ميراث الاولادوالابوين والثانية (r ا من سـورة النسـاء) في ميراث الزوج والزوجة والثالثة ( IVT من سـورة النسـاء ) ذكر فيها ميراث الكلالة ـ ووردت آيات المواريث في

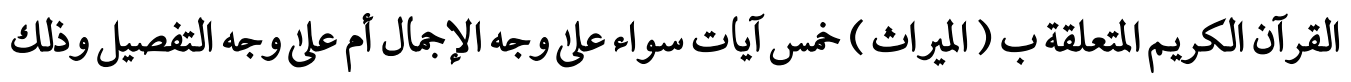

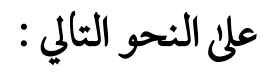

\section{ا- الآيات المجملة}

آ- قوله تعلالي : (للرجال نصـيب مالما ترك الوالدان والاقربون وللنسـاء نصـيب مما ترك الوالدان والاقربون مما قل منه أو كثر ذصييا مفرو ضا واذا حضر القسمة أولو القربئ واليتامئ والمساكين

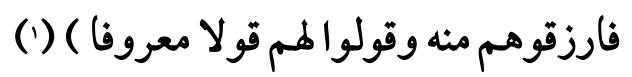

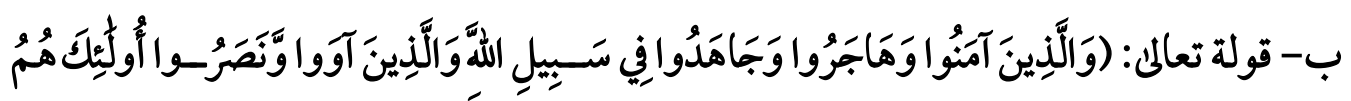

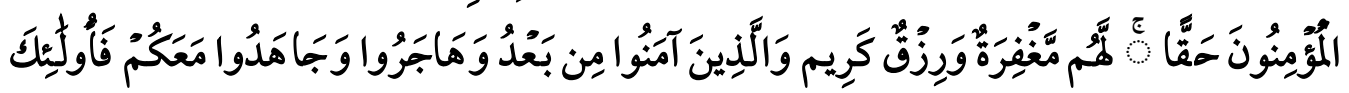

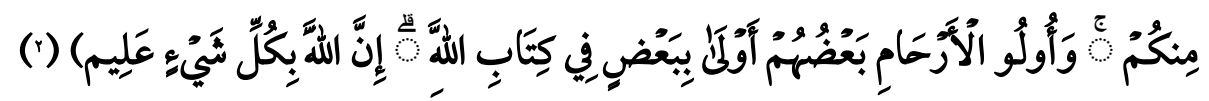
r- الآيات المفصلة: أ- قولة تعلالن: (يوصيكم الله في أولادكم للذكر مثل حظ الأنثين فإن كن نساء فوق اثتين فلهن ثلثا

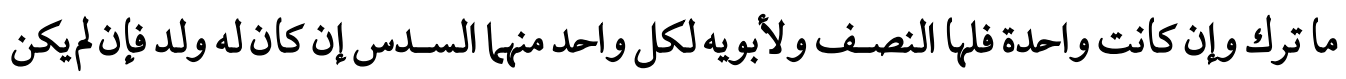

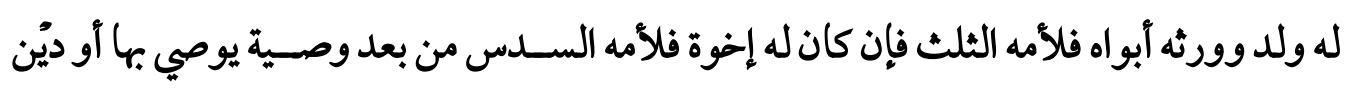

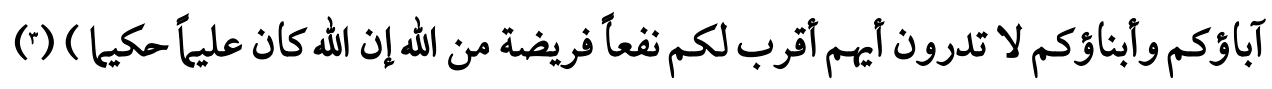

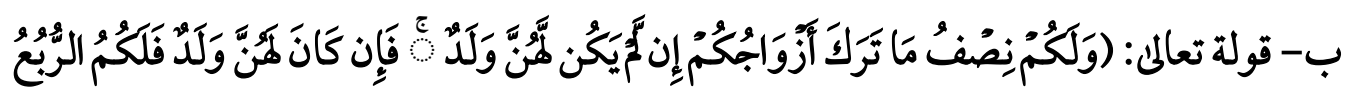

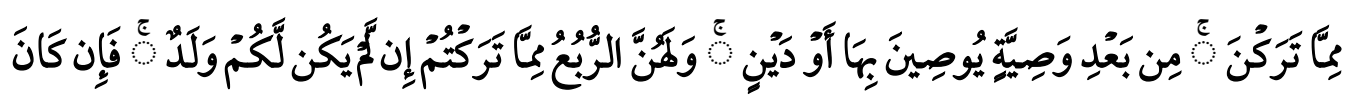

1 ) سورة النساء الآية N-V

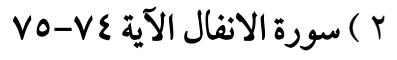

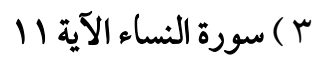




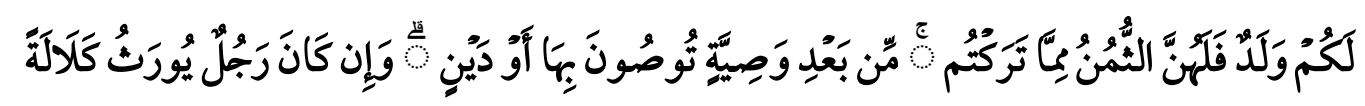

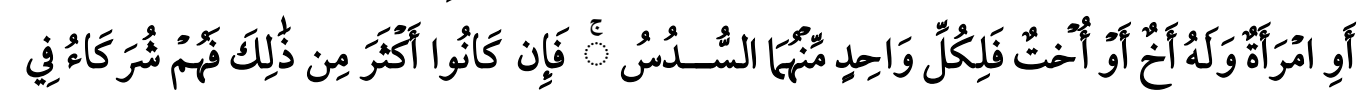

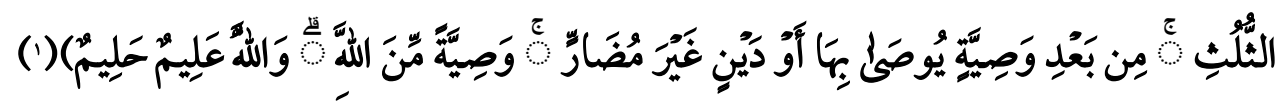

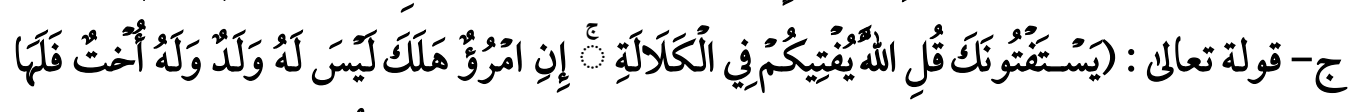

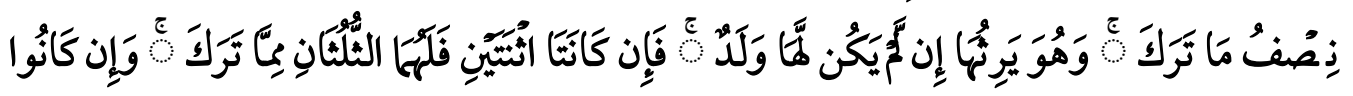

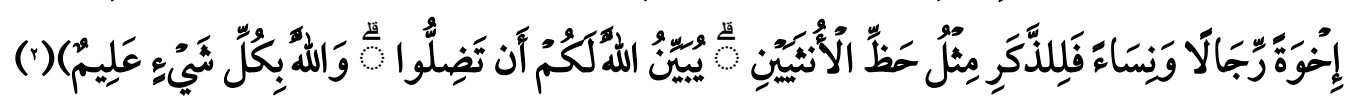

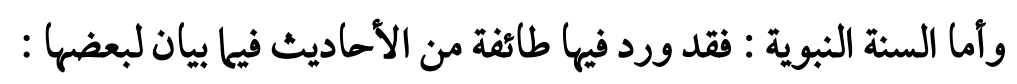

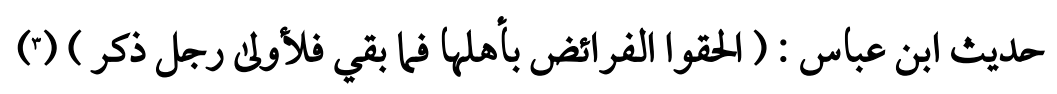

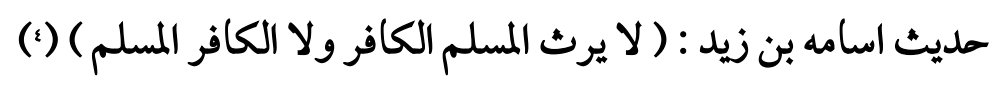
حديث عبادة بن الصـامت: (أن النبي صـلن الله عليه وسـلم قضئ-للجدتين من الميراث بالسـدس بينه|)( بين حديث ابن مسعود في بنت وبنت ابن وأخت : قضئ النبي صلئ الله عليه وسلم للابنة النصف ولابنة الابن السدس تكملة للثلثين وما بقي فللأخت ) ( ) واما الاجماع: فهو اجماع الصسحابة والتابعين علنى أن فرض الجدة الواحدة الســس وكذلك فرض الجلتين والثلاث، كما حكى البيهقي عن محمد بن نصر- من أصــحاب الثـافعي لكن الثـافعية

\author{
| () سورة النساء الآية r|

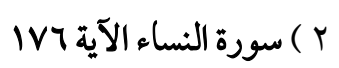

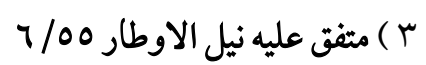

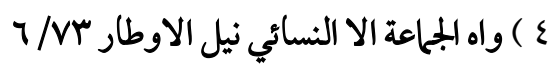

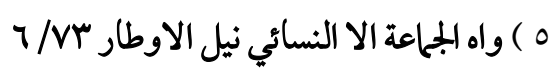

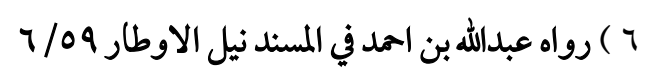


والمالكية لا يورثون الا جدتين. وكا في توريث أم الاب باجتهاد المليفة عمر ، وموافقة الصسحابة،

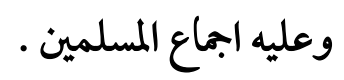

وقد اجمع الصحابة والتابعون ومن بعدهم علئ مشروعية الفرائض ولميخالف في ذلك أحد (1) .

' ) مشروعية علم المواريث من الكتاب والسنة والاجماع ، الشيخ السعيد عبدالعال ، معهد دار المجرة للقراءات

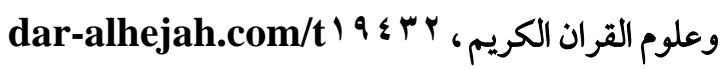




\section{المبحثة الثاني \\ أهمية علم المواريثُ ومكاتقه في الإسلام}

أهمية علم المواريث بِ القران الكريم

تولى الله تقدير الفرائض بنفسـه ، ولميترك ذلك إلي الملائكة والرسـل فيين حق كل وارث سـواء من النصف والربع والثمن والثلثين والثلث والسدس وفصلها غالبا، بخلاف سائر الاحكام الشرعية

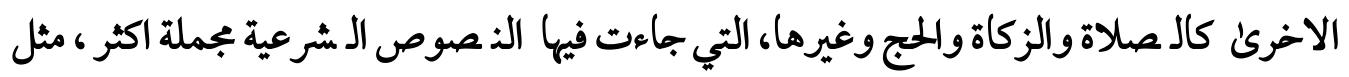
قوله تعالنى (وأقيموا الصلاة وآتوا الزكاة) ( ) وقوله تعاله : (ولله علني الناس حج البيت من استطاع

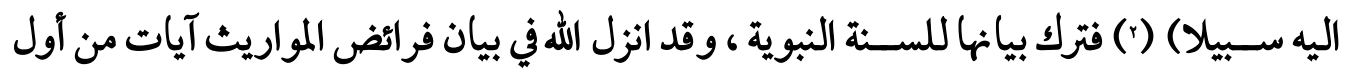
سـورة النسـاء ومن آخرها وسـمئ هذه الفر ائض حدوده، ووعد من اطاعه في تنفيذها على الوجه

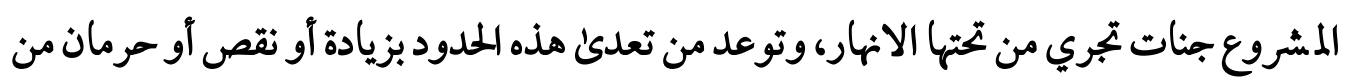

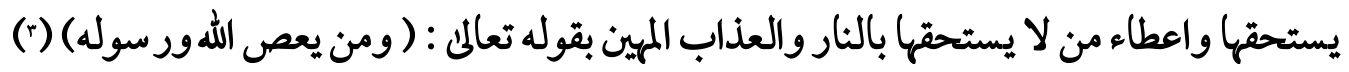

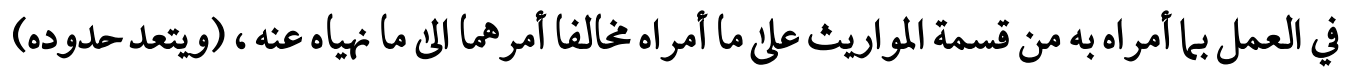
أي يتجاوز فصول طاعته التي جعل تعالئ فاصلة بينها ويين معصيته المي ما نهاه عنه أن (يدخله نارا

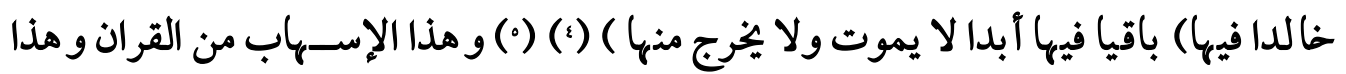
التفصـيل الواضـح في أحكام المواريث تدل دلالة واضـحة علئ مكانة هذا العلم ، وأثره في حياة الناس، لأن فيه معاث لهم، ويساهم مساهمة بينة في معالجة وإخفاء لبعض حالات الفقر والعوز في

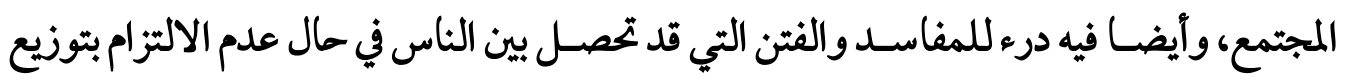

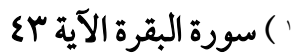

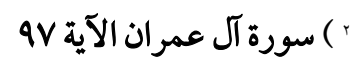

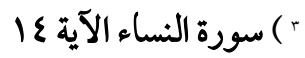

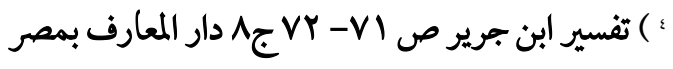

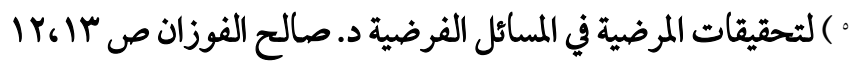


الميراث وفق ما أمر الله تعالث، إضافة إلى ما يتجج عنه من تولد القطيعة بين الأرحام، وتعمق الكراهية والمقد والمسد فيا بينهم.

\section{مكانة علم المواريث يو السنة النبوية :}

لقد سارت السنة النبوية علن منهج القرآن الكريم في إيلاء أحكام المواريث الاهتحام اللائق بها، وقد أوضـحت السـنة النبوية المطهرة أحكامه، وفصـلت ما ورد ذكر من أحكام واردة في آيات الكتاب

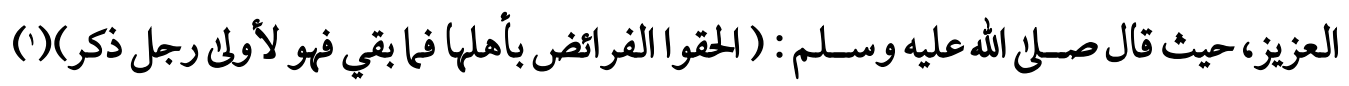
وقال صلن الله عليه وسلم: ( تعلموا الفرائض وعلموها فإنها نصف الع-----_ـلم وهو ينسئ وهو

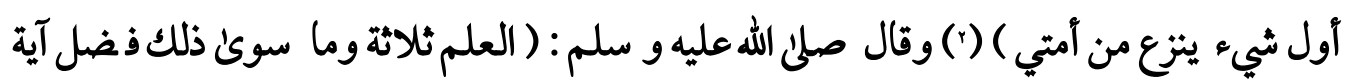

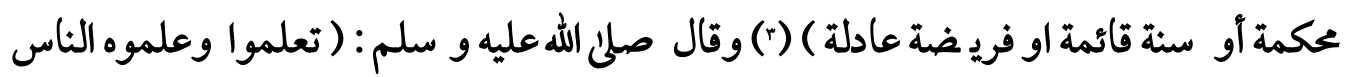

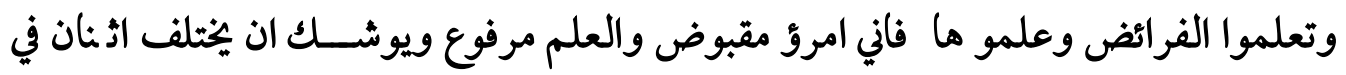

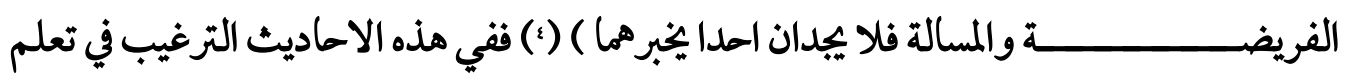
الفرائض فهي تحمل عناية خاصـة بهذا العلم الجليل تعليا وعملا مما يدل على اهميته - ولعل من

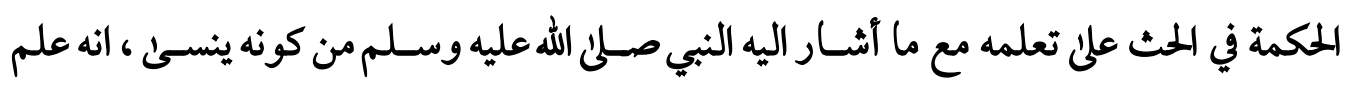

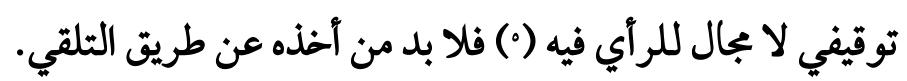

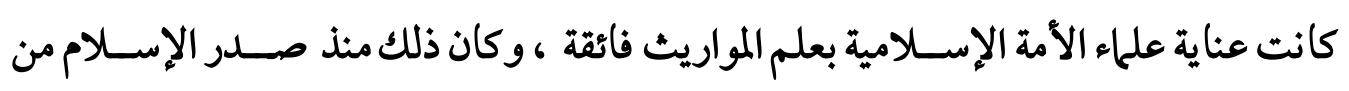

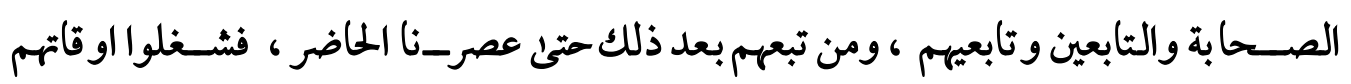

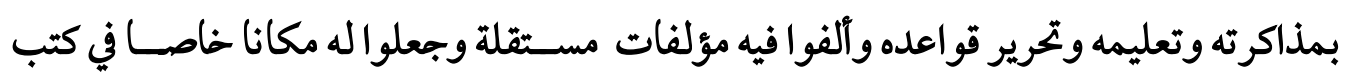

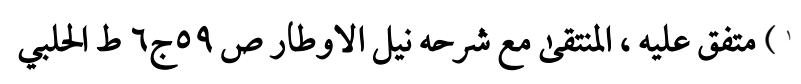

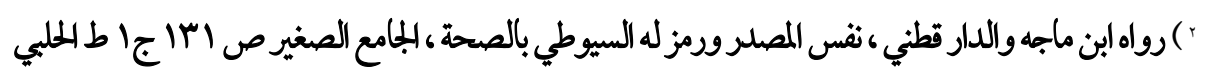

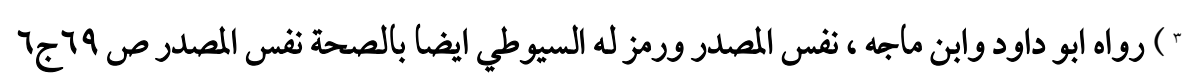

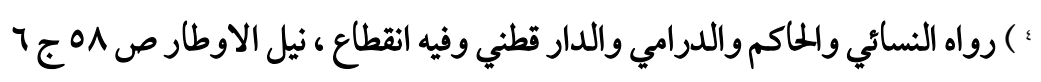

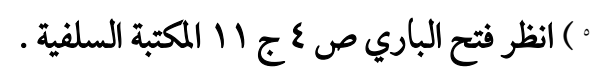


الفقه العامة فما من كتاب فقه خختصر- أو مطول إلا ويشـغل كتاب الفر ائضل حيزا كبيرا منه ، فعلوا

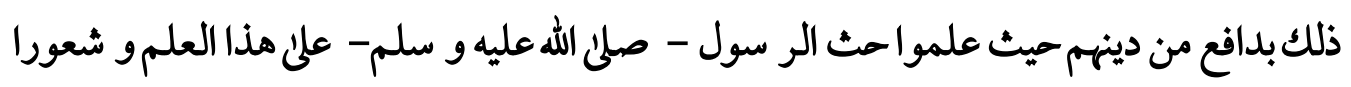

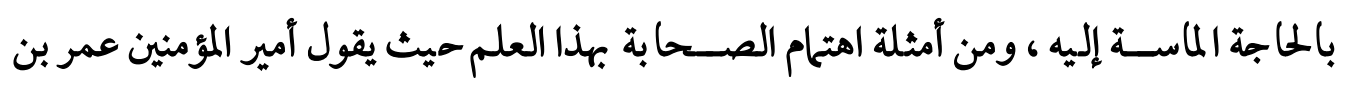

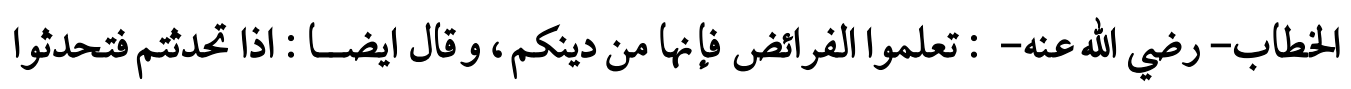

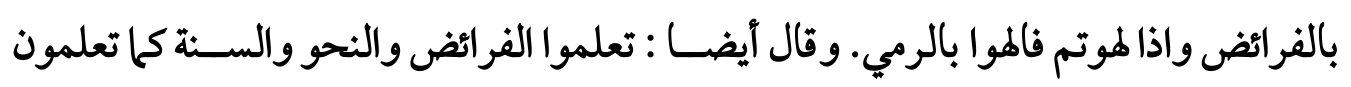
القرآن(') وعن ابن عباس رضي الله عنها في قوله تعالى : ( الا تفعلوه (') الآية - معناه ان لمترأخذوا

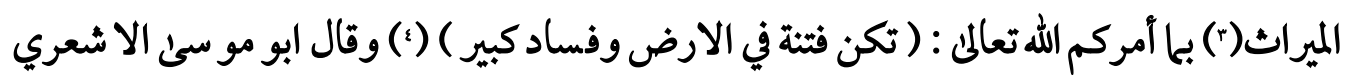

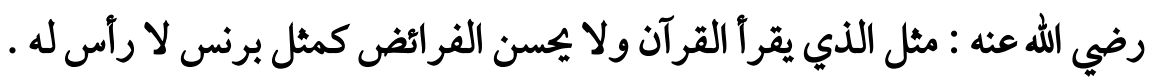

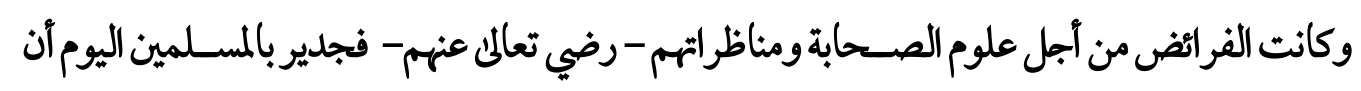

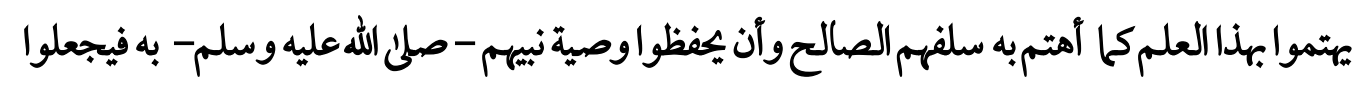

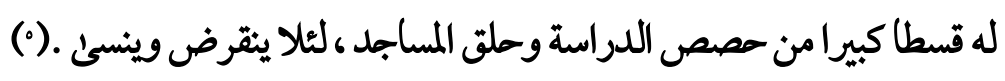

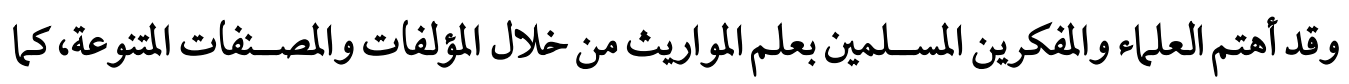
اهتمت الجامعات الا سلامية وكليات الشريعة في الاقطار الا سلامية والعربية وتدريس هذا العلم وادراجه في الخطط الدراسية والمقررات.

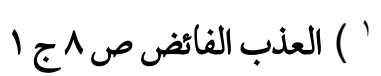
r r ) سورة الانفال الآية Vr

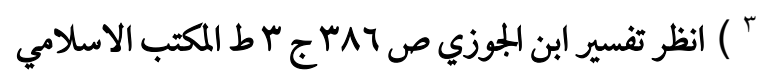

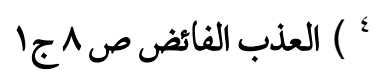

• ) التحقيقات المرضية في المباحث الفرضية د. صالح بن فوزان الفوزان ص 17، 17 


\section{المبحث الثالثه}

\section{مزايا نظام الميراث في الإسلام}

إن ميزات وخصـائص نظام الإسـلام في المواريث كمزاياه في جميع تشر-يعاته ظاهرة للعيان

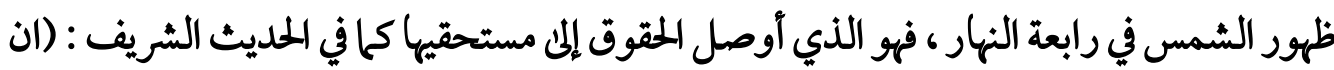
الله قد أعطى كل ذي حق حقه فلا وصـية لوارث) (') وإذا كانت الباهلية راعت الآقوياء وحرمت الضعفاء من الميراث فإن الإسلام راعي هؤلاء الضعفاء لأنهم أحق بالعطف والمعونة كما قال صلئ الله عليه وســم (إنك إن تذر ورثتك أغنياء ، خير من أن تذرهم عالة يتكففون الناس) (() ولميحرم

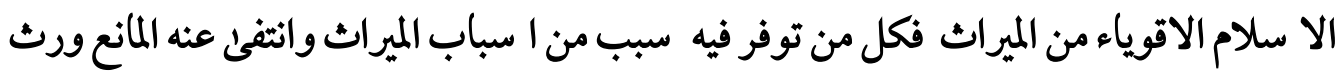

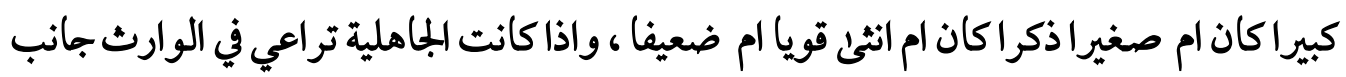

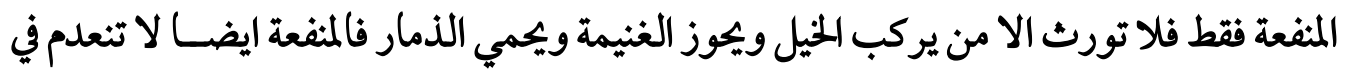
غير هؤلاء بل قد يكون غيرهم اقرب منهم للمتوفي نفعا كما قال تعالم: (آباؤكم وأبناؤكم لا تدرون

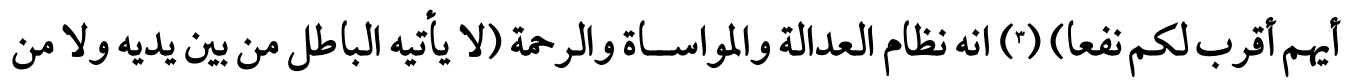
خلفه تنزيل من حكيم حميد) (؛) وقد تميز نظام التوريث في الإسلام علئ غيره من الانظمة سواء في البلهلية أو قبل الإسلام أو الوضعية الحديثة وذلك من خلال امور عديدة علن النحو التالي:

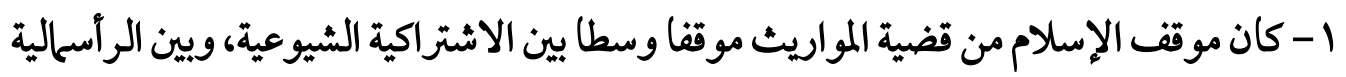

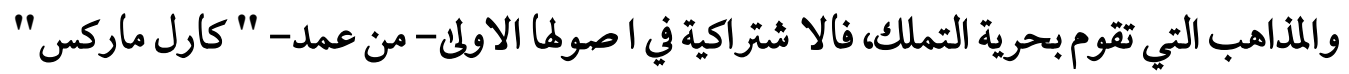
تنكر مبدأ الارث ،وتعتبره ظلما يتنافن مع مبادئ العدالة، فلا تعطي انباء الميت واقرباءه شيئا مطلقا، والرأسمالية وما شابها من المذاهب الاقتصادية تترك الحرية كاملة للرجل يتصرف في حالة كما يشاء

' ' ) رواه الخمسة الا ابا داودوصححه الترمذي صَّع جَ المتقىى مع شرحه نيل الاوطار

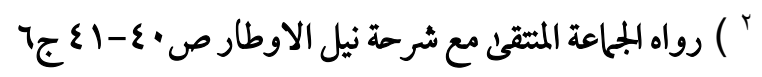

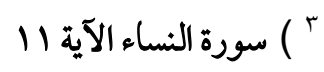

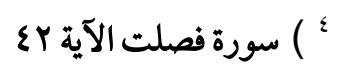


دون ضــوابط، فله ان يحرم اقرباءه كلهم من الميراث، وله ان يوصي بجاله المن غريب من صــديق او

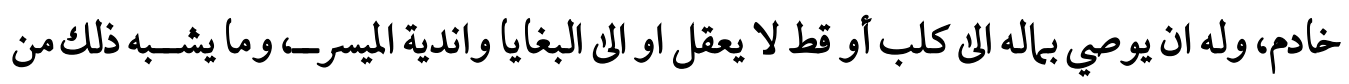

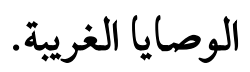

لقد أعطى الإسلام للإنسان الحرية الكاملة في التصرف في ثلث ماله ، سواء على سبيل الوصية أو

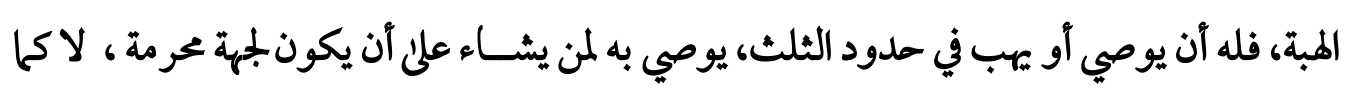

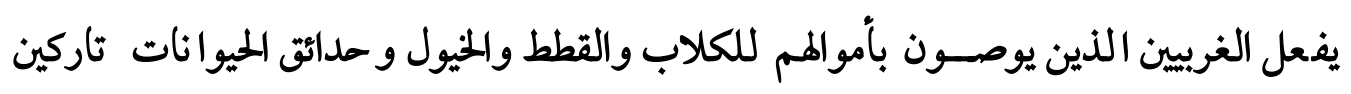

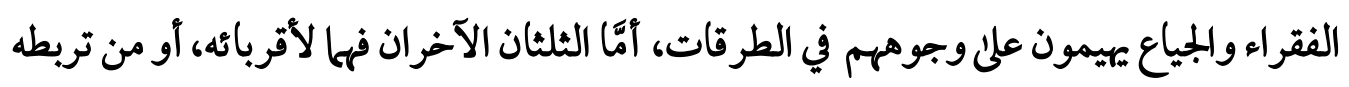

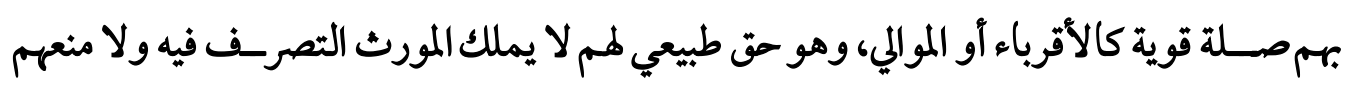
منه، وبذلك يكون الإسـلام قد حفظ حق الورئة في حياة صـاحب المال، فنظرية الإسـلام الثابتة أنه ئه بمجرد ما حل بالإنسـان مرض الموت يمنع عليه التصرـف بأمواله من أجل عدم إلماق الضرــر

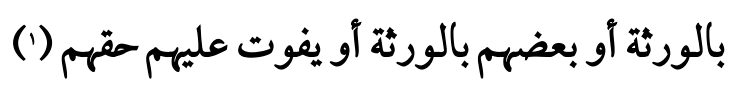

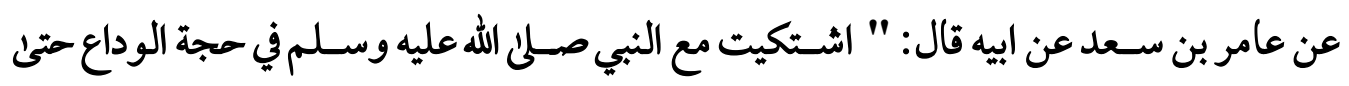

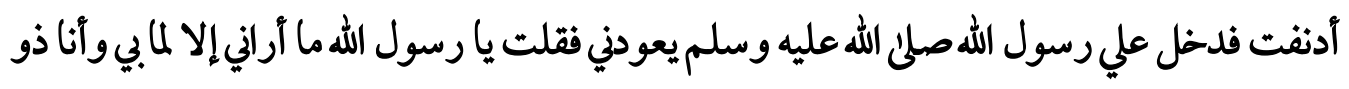

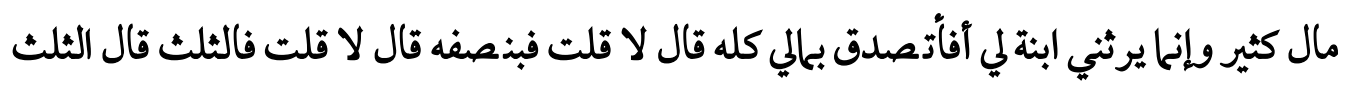

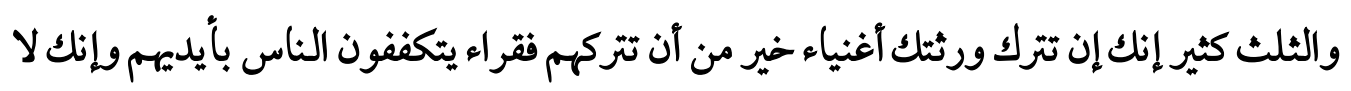

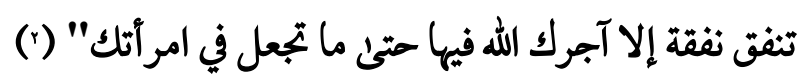
وا شترط الا سلام في صحة الو صية كذلك أن لا يقصد بها مضارة الورثة، فقد روئ ابو هريرةرضي الله عنه-عن رسول الله صلنى الله عليه وسلم- قال: "إن الرجل ليعمل والمرآة بطاعة الله ستين

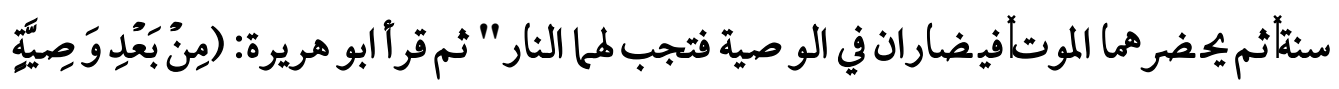

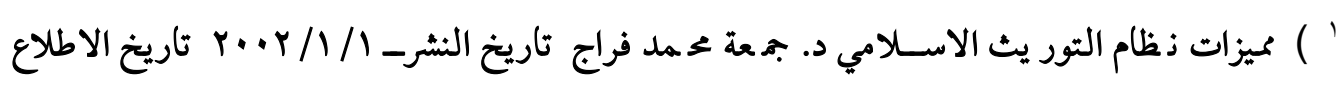
https://www.islamweb.net/ar/article/ roov، r. r / / / / . ' ) رواه ابو داود والترمذي 


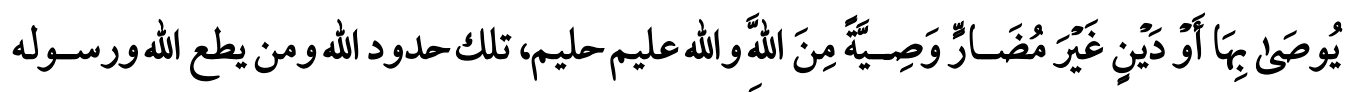

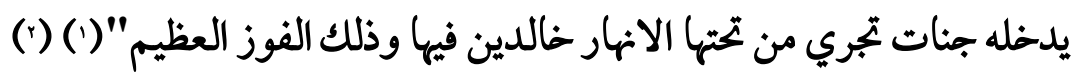

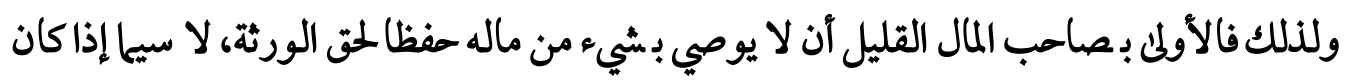
المال لا يسمح بقضاء حاجات الورثة، وخاصة إذا كان الورثة صغار ابحاجة إلى تربية ونفقه (r)

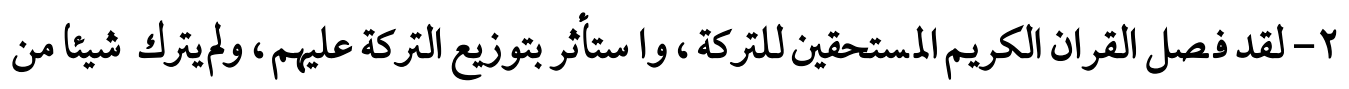

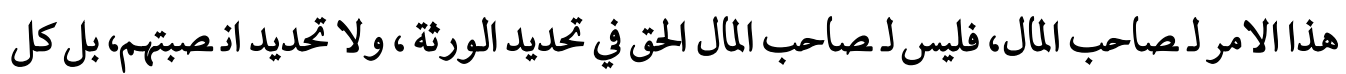

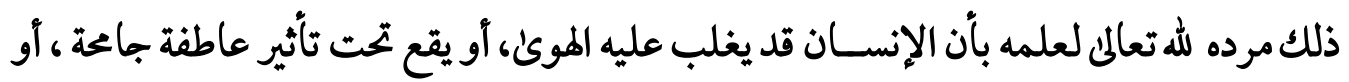

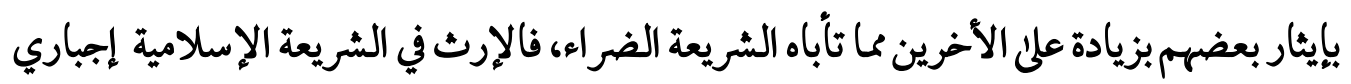

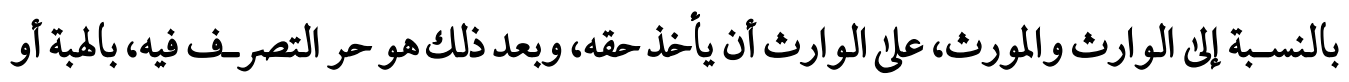
الصدقة أو التنازل عنه لأي شخص ، أما المورث فيجب عليه أن يذعن لقسمة المولى العليم المبير.

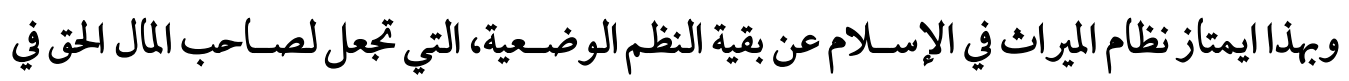

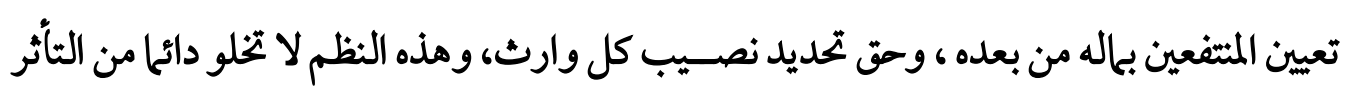
ببعض المؤشرات التي سبقت الإشارة إليها .

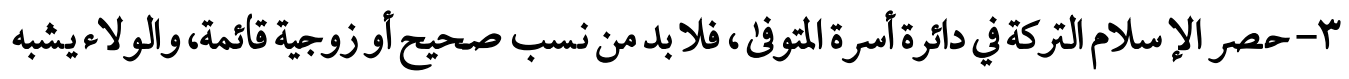

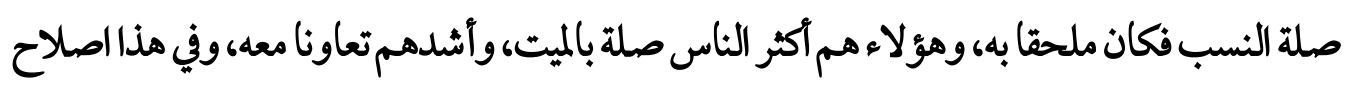

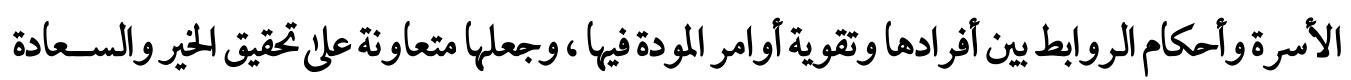

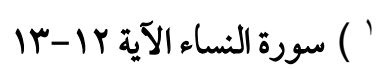

† ' ) رواه ابوداودوالترمذي وقال حديث حسن صحيح غريب ورواه الامام أمد وابن ماجه والحديث ضعفه

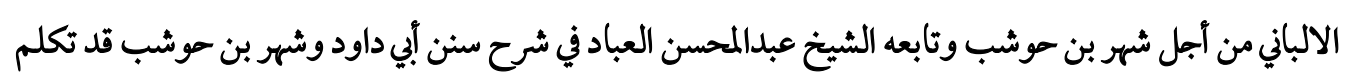
فيه غير واحد من الائمة ووثقه احمد بن حنبل ويجيحل بن معين كما قال المنذري .

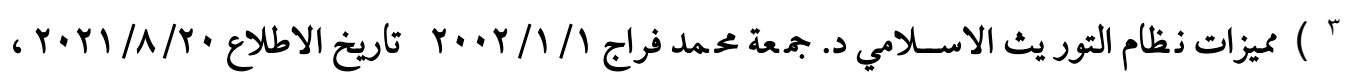
https://www.islamweb.net/ar/article// r rov 
في حياتها وفي داخل الأسرة الواحدة يفاضل الإسلام بين الورثة بحسب قربهم أو بعدهم عن المثوفن ،من

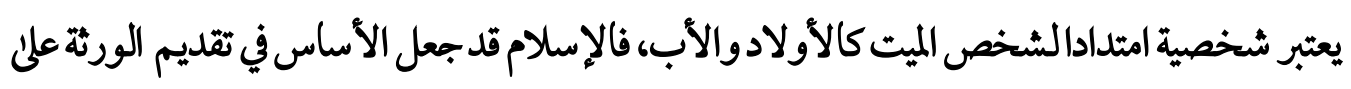
بعض قوة القرابة، واتصال المنافع بين الوارث والمورث .

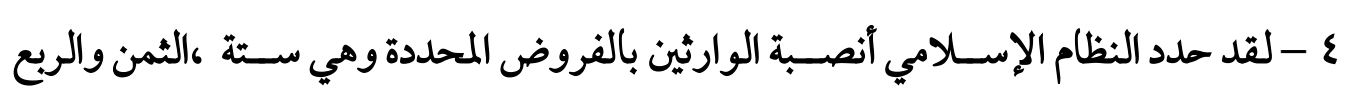

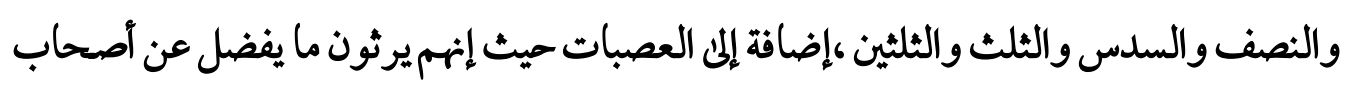
الفروض، ولا مثيل لمذا في الشرائع القديمة والحديثة، وهذا محصور في الإسلام ولا مثيل له في غيره من الأنظمة . مروبك.

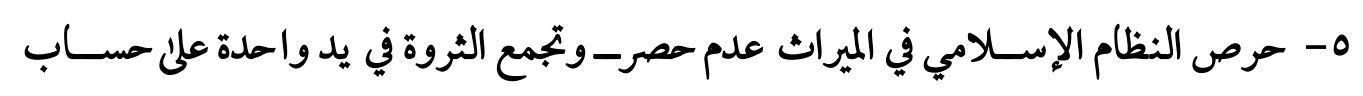
الأخرين، وهذا بدوره يؤدي إلما تفتيت الثروة وتوزيعها بين أكبر عددميكن من الناس المستحقيعين،

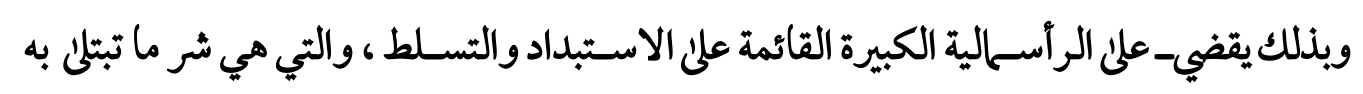
المجتمعات، وتنزلق بها المى مداخل الفساد والمذاهب المدامة ـ (').

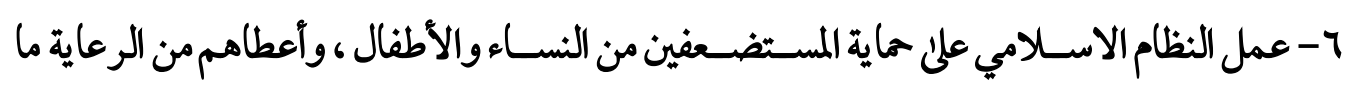
يستحقون ، فجعل للنساء ذصييا من مال الميت، يحفظ حياتهن وكرامتهن ويحول بينهن ويين ذل اللحاجة

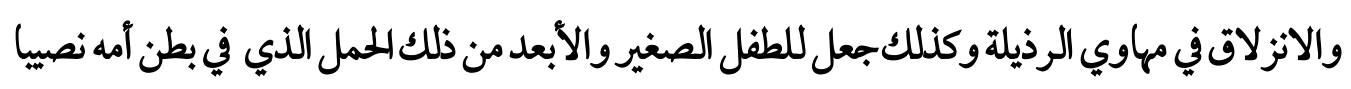

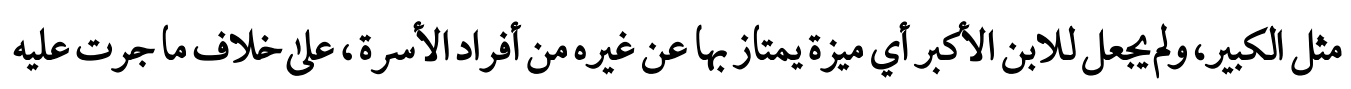

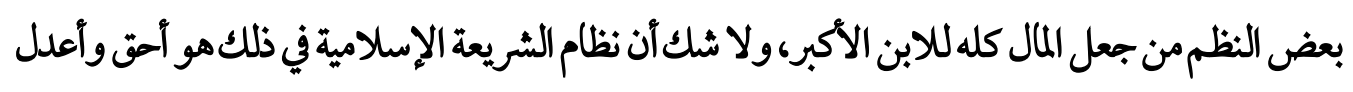

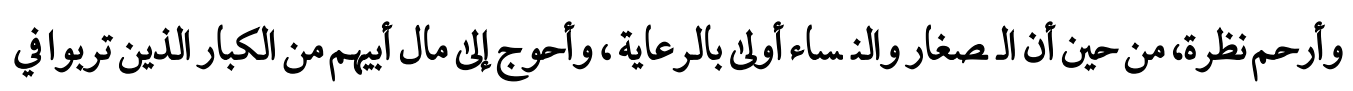

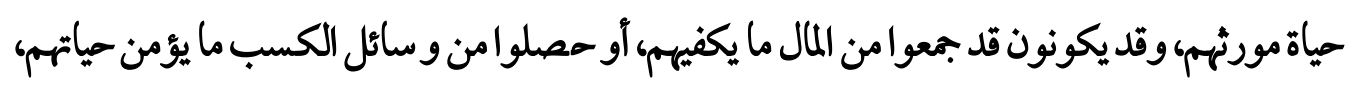
وييعلهم في رغد من العيش بعكس الصغار .

' ( ) المرجع السابق 
V اعتبر النظام الإسلامي الزوجية الصحيحة من الأسباب الموجبة للميراث، فالزوجة ترث من

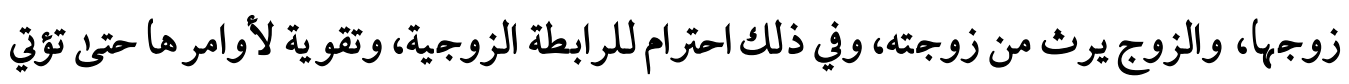

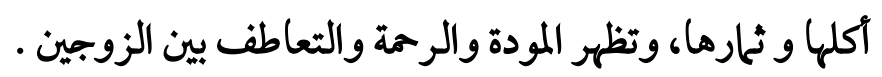

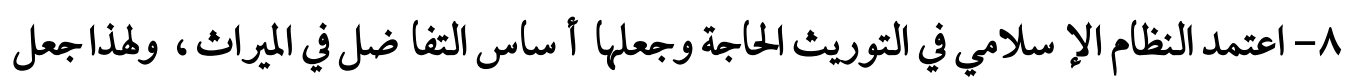

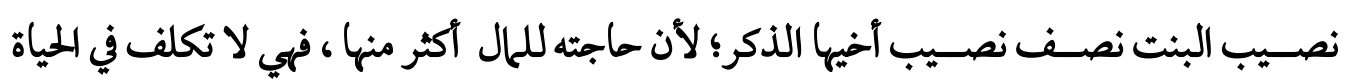

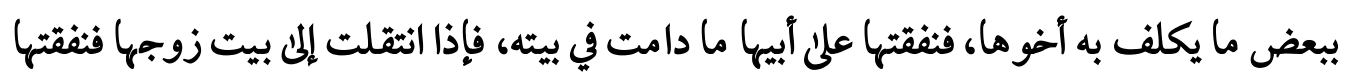

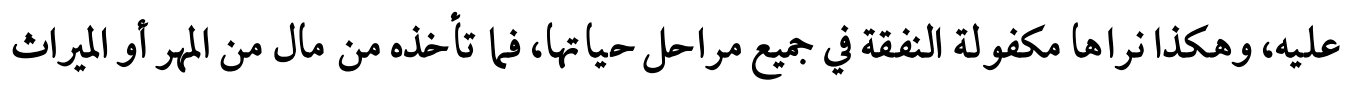

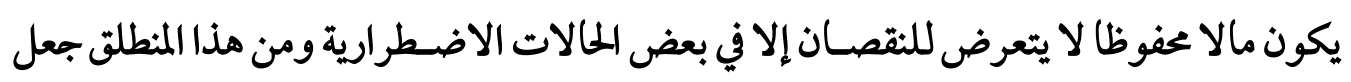

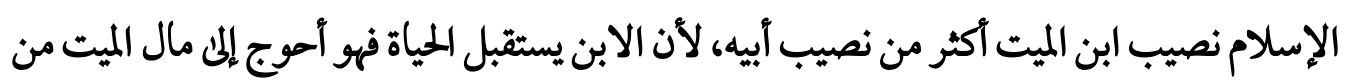

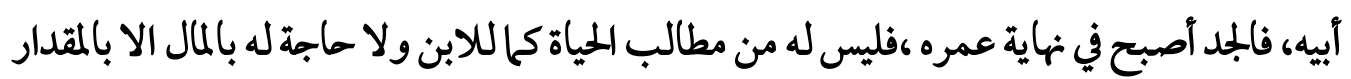

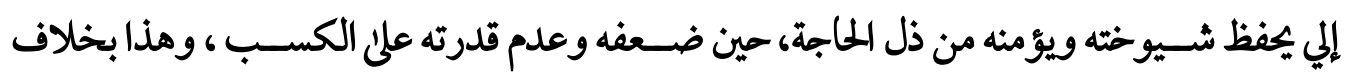

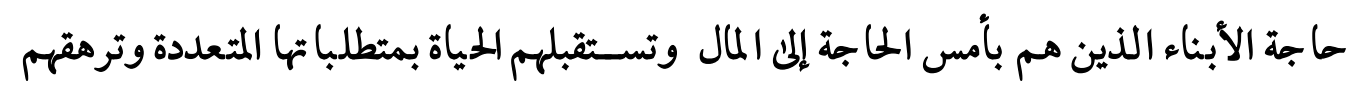

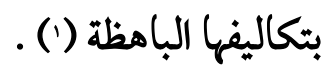

فهذه المميزات جعل نظام الميراث الاسلامي هو النظام الامثل بين الأنظمة المختلفة من جميع النواحي الاجتحاعية

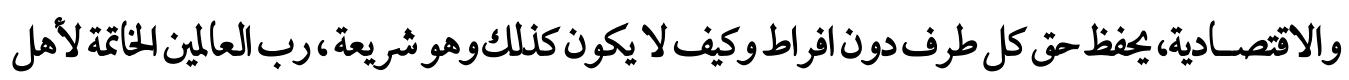

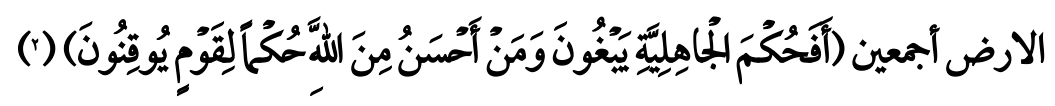

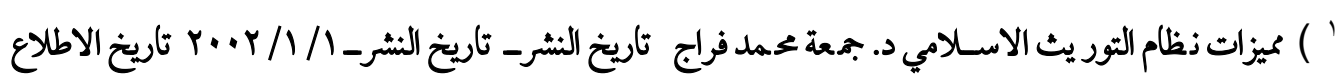
https://www.islamweb.net/ar/article/ roov r.r. r / / / / r.

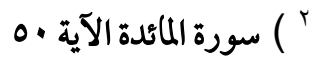




\section{المبهث الرابع}

\section{وسطية نظام الإرثق ومدالته في الإسلام}

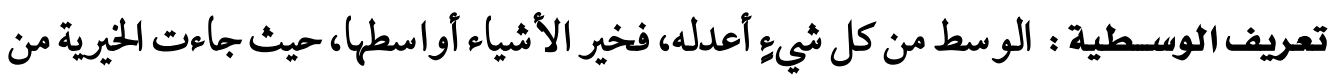

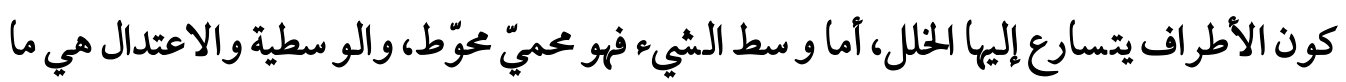

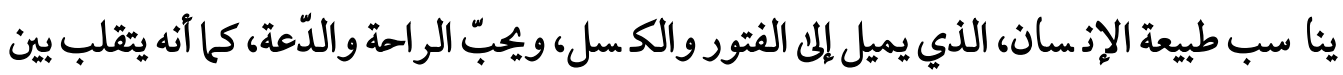
قوة وضسعف، وصسحة ومرض، فجاءت الوسطية متفقة مع حاله، فالأمة الإسـلامية وسطية في لئي

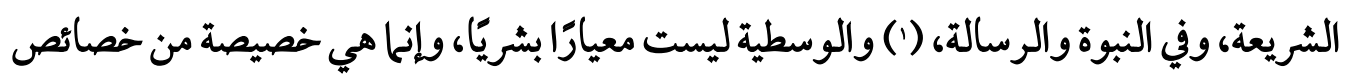

الإسلام، وميزة تميزت بها الشريعة، فيلاحظ هذا المفهوم في جوانب الإسلام وجزئياته كافّة.(")

مظاهر الوسطية ف2 الاسلامم

تتمثل مظاهر الوسطية في الإسلام بعدة مظاهر وذلك علام النحو الآتي :

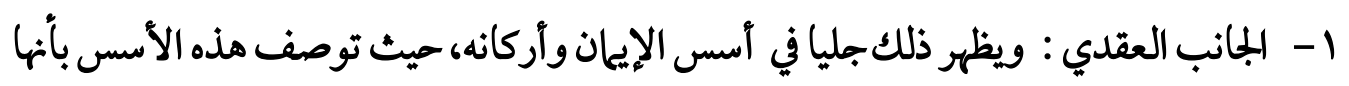
خالية من التعقيد، والطلاسـم، والغموض، فدلائل وجود الله واضـحة جليّة، وأصــول الإيمان

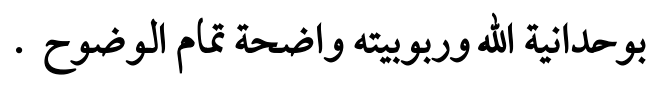

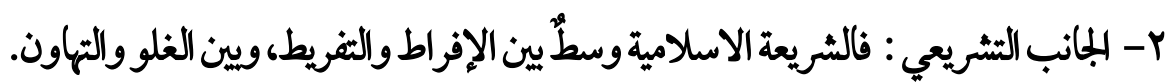

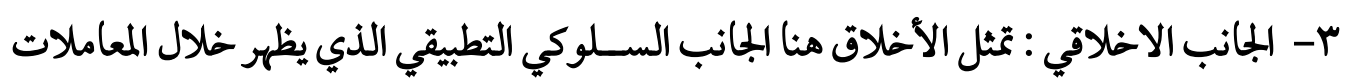
بين الناس، فعماده التو سط في الإنفاق بين الإسراف والثقتير، والو سطية بين القضاء والاقتضاءهاء وغيرها من الأمور.

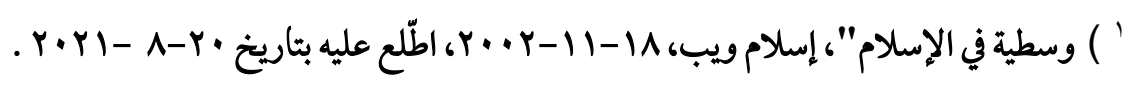

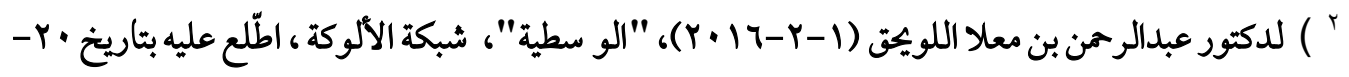
A 
ع - البانب الدعوي : إذ إن منهج الدعوة في الإسـلام يقوم علني مخاطبة الآخرين بالحكمة والموعظة

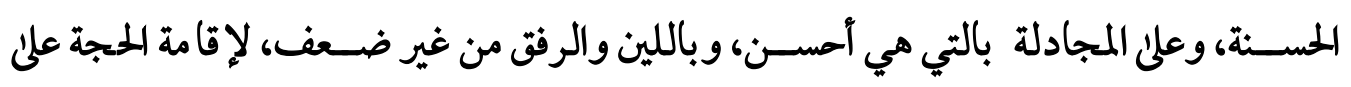
المخالف، وإقناعه بالتي هي أحسن ـ (') وهذا يدلل علن أن الوسطية في الشريعة الإسلامية شاملة جميع النواحي والجوانب ولا تقتصر على لن

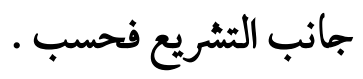
ضوابط الوسطية فِ الاسلام هناك جملة من الضوابط تحكم الوسطية في الإسلام من أهمها ما يلي :

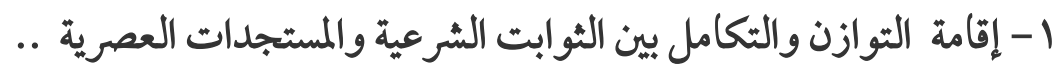

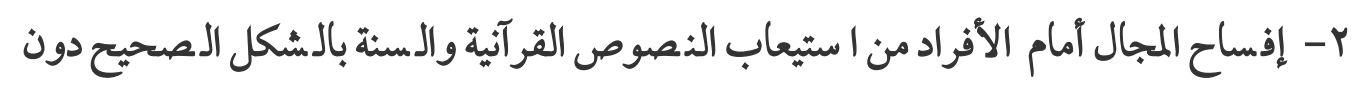
مغالاة أو تشددّ.

r- التيسير والتسهيل في الأحكام والفتاوي ضمن حدود الشرع الحنيف .

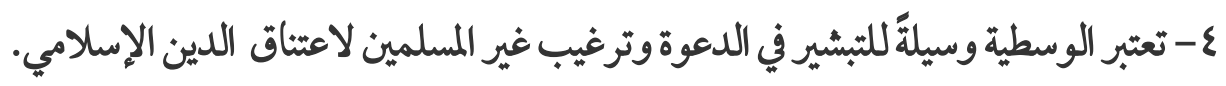

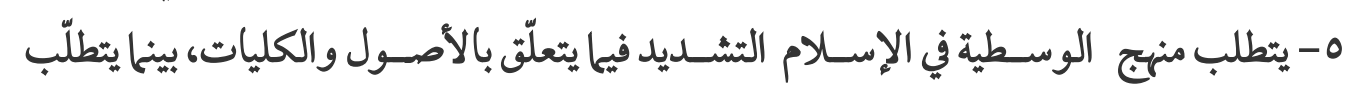
التيسير في الفروع والجزئيات. 1 - اتبع الإسلام أسلوب الدعوة بلحكمة والموعظة الحسنة، وفتح أبواب الحوار مع الآخرين. V- اتبع الإسلام أسلوب السلملمن جنح إليه وعلم محارية الاعداء ، والقتال مع من جنح للقتال.

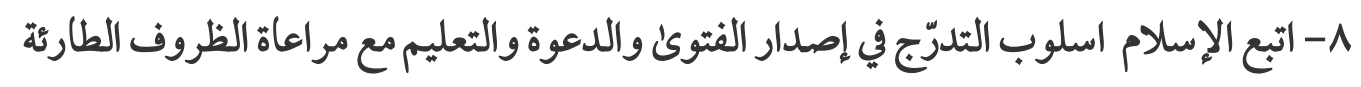

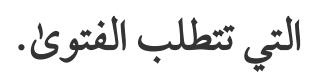
9- ركز الإسلام حول على القيم الإنسانية الفاضلة كالعدل والشورئ.

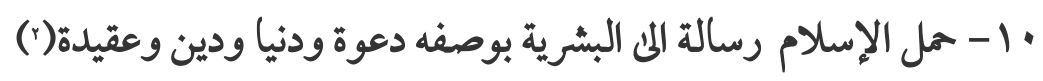

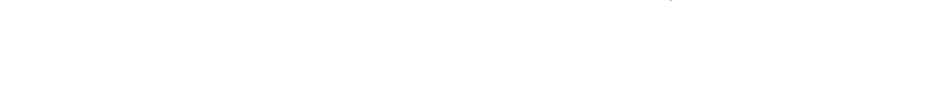

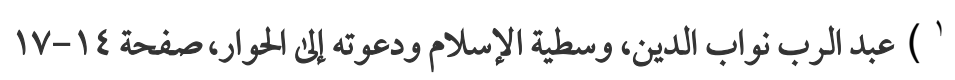

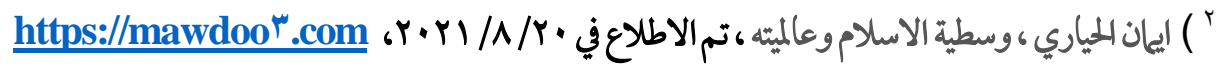


أهمية الوسطية فِ الإسلام

للوسطية أهمية كبيرة في حياة الامة تتمثل في الجوانب الاتية: (1) (1) وتد وتدعو الوسطية المسلمين على الالتزام بتعاليم الدين الإسلامي وأحكامه.

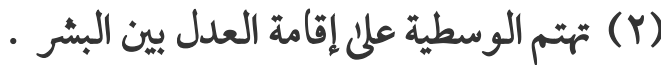
(r) تسعى الوسطية إلى نشر الخير والبر بين العباد.

(ع) تهدف الوسطية إلى إقامة الحلافة في الآرض وهي عمارتها وعبودية الله سبحانه وتعالها. (0) وسطية الإسلام تعطي كل ذي حق حقّه الإنساني وتظهر الوسطيّة الدين الإسلامي على حقيقته.

(7) الوسطية أرقى وسيلة لدرء الشبهات وإبعاد كل التهم التي ألصقت بالإسلام (') وقدوقف الإ سلام موقفا و سطا بين الا شتراكية الشيوعية، وبين الرأ سمالية ولمذاهب التي تقول بالحرية الشخخصية في التملك، فالا شتراكية الشيوعية كحاو ضعها كارل ماركس تنكر مبدأ الإرث وتعتبره ظلما يتنافف مع مبادى العدالة، فلا تعطي أبناء الميت واقربائه شيئا مطلقا. والرأسمالية وما يشابها من المذاهب الاقتصادية تترك مطلق الحرية للمورث في التصرف بجاله كيف شـاء، فله أن يحرم اقرباته كلهم من ميراثه، ويوصي به إلى غريب ، من صــديق أو خادم، ويوصي الرجل أو المرآة في المجتمعات الغربية بكل ثرواتهم آو بعضـها لكلب أو قطة أو ما آثـــه ذلك من

الوصايا العجيبة الغريبة (r). ولإظهار فلسفة الإسلام ووسيطته يِ ثـان الميراث لا بد أن نقارن بينه وبين الأنظمة الأخرى لتظهر لنا وسطيته : الميراث عند اليهود :

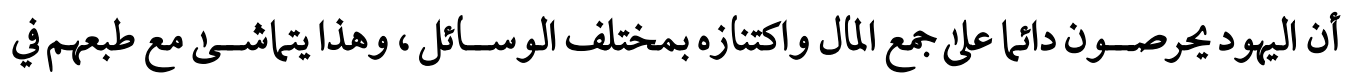
العيش حيث يعيشــون متهاسـكين، ومن أجل ذلك كان من البديهي حرصههم كل الحرص علني عدم

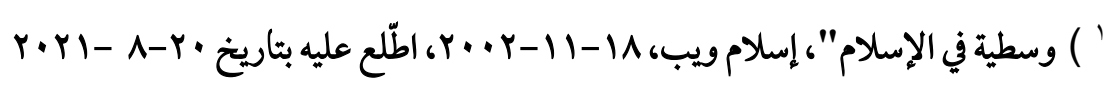

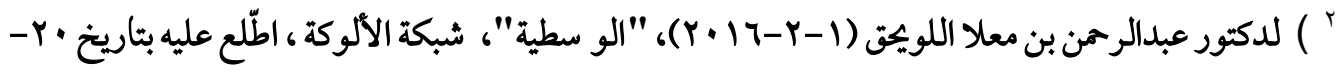
https://www.islamweb.net/ar/print.php?id=101 $1 r^{\prime}|r \cdot r|-\Lambda$ 
توزيع ثروة الميت خارج أسرته لكي تحتفظ الأسرة فيا بينها بأمو الما التي تعبت في جمعها ، وتعتز بها

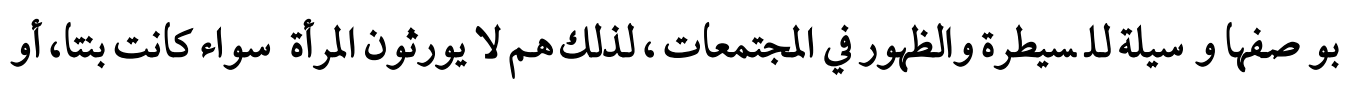
أما، او زوجة او اختا، ما دام يوجد لهذا الميت ابن أو اب أو قريب كالأخ والعم، ، فالذكر يقدم دائما

على الأنثى وللشخص الحرية الكاملة في ماله يتصرف به كيف يشاء بطريقة المبة او الوصية(')

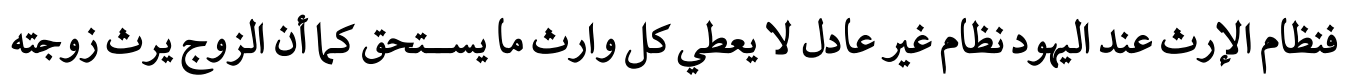

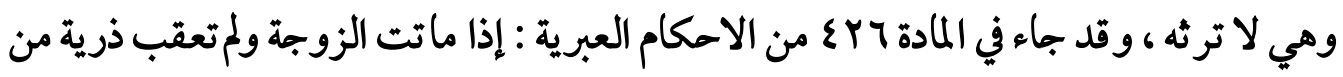

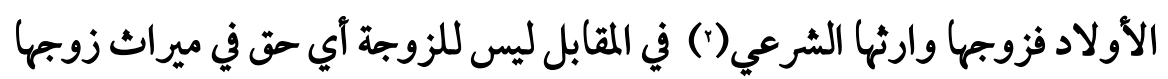

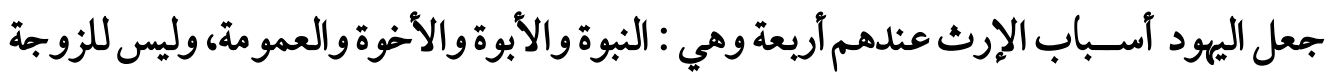

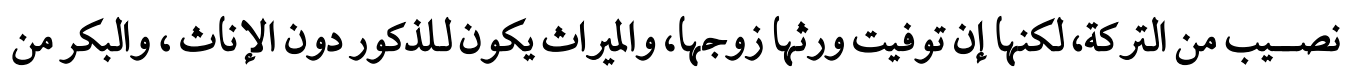

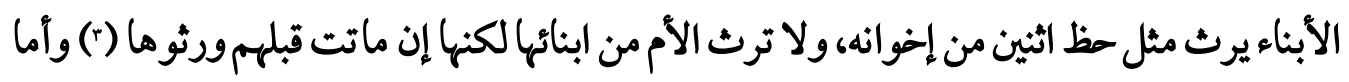

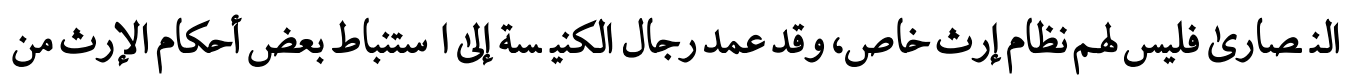
التوراة، وفي بعض الدول العربية يطبق النصارئ نظام الإرث الإسلامي. الميراث يُ الجاهلية : فقد كان العرب قبل مبعث رســـل الله - صــلن الله عليه وســلم - يورثون ولكنهم يورثون وفق

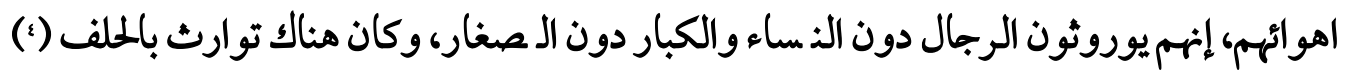
وكان يعللون ذلك بقولمم: لا نعطي من لا يركب فرسـا، ولا يجمل كلا، ولا ينكي عدوا(·) إنهم

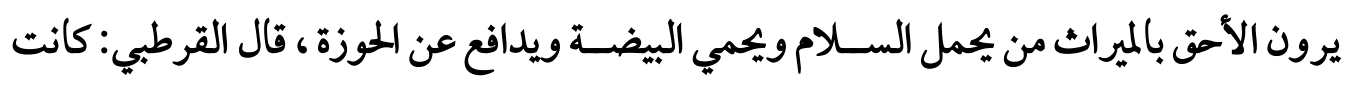

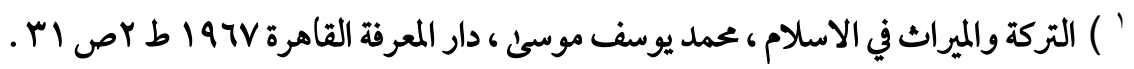

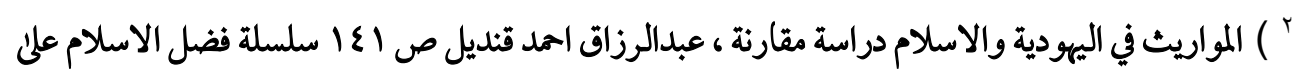

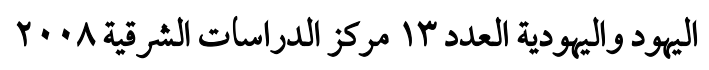

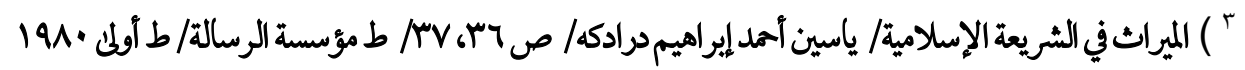

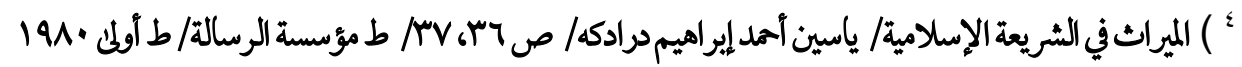

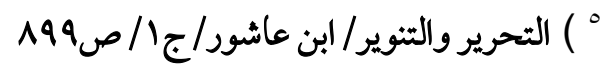


الوراثة في الجاهلية بالرجولة والقوة، و كانوا يورثون الر جال دون النســــ (') و كان العرب في الجاهلية يرجعون الإرث إلى ثلاثة أسباب هي: النسب سواء أكان من زواج صحيح أم زنا ، والتبني حتى لمن كان معروفا نسبه، والحلف والمعاقدة(') ولما جاء الإ سلام بتشريعاته الربانية، التي لاتحبي قويا، ولا تظلم ضعيفا ولا تحرم مـ ستحقا، ولا

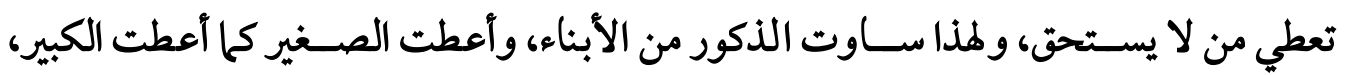
وأعطت الإناث والضعفاء، وراعت درجات القرب من الميت، فليس كل الأقارب سواء. حتى لو كتب الزوج أمو اله لزوجته، فإذا هذا يعتبر وصـاية لا وصـية، فليس للزوجة ورجة إلا الحقوق

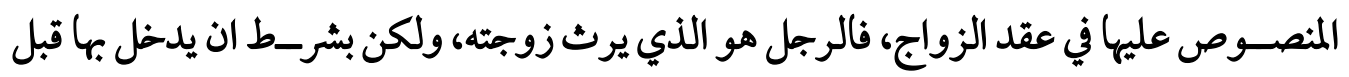
الوفاة، وإلا يكون بينها وبينه خصـومة بسـببه، فإذا توفيت والرجل علني كرهة لما فلا إرث له عنها، وكذلك لو توفيت وكان لميدخل بها. ويالنســـبة لميراث البنت: القاعدة العامة في التشريع اليهودي توجب أن تركة المتوفي للذكور دون الإناث وعلن الذكور نفقة البنات وتربيتهن حتى يتزوجن، سـواء كان ذلك الميراث في تركة الأب

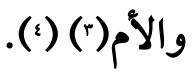

\section{نظام الارث في الديانة المسيحية}

يعتبر المسيحيون العهد القديم كتاب الشريعة والعهد المجديد عهد الفضل والكفارة، وتعليل ذلك آن الأناجيل خلت من الأمكام التشر-يعية، فعلم المسـيح عليه السـلام آتباعه تطبيق الديانة اليهودية خاصة في شقها التشريعي لأنه لميأت بتشريع جديد، ولميأت لينقض شريعة موسئ (•) وبالتالي ليس

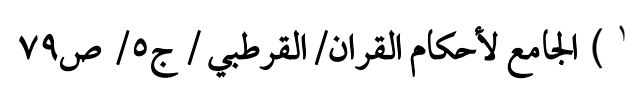

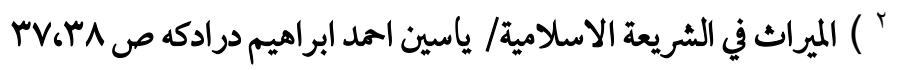

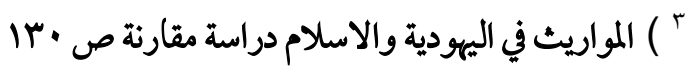

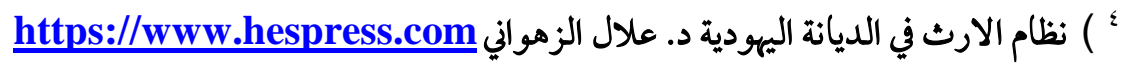

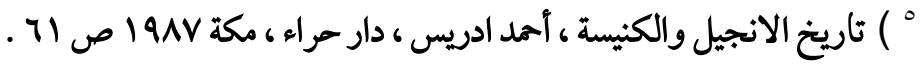


في الديانة المسـيحية تشر-يعات خاصـة بالميراث بل كل ما جاءت به شريعة موسـئ ينطبق على الن

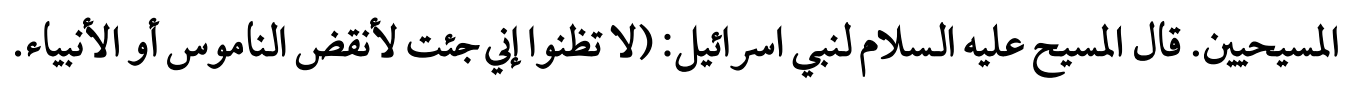

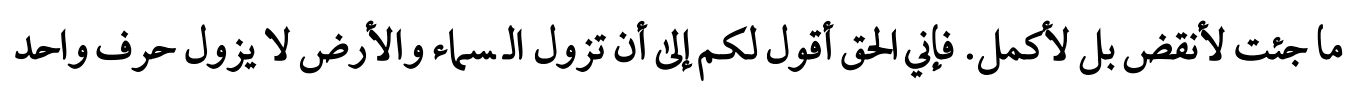

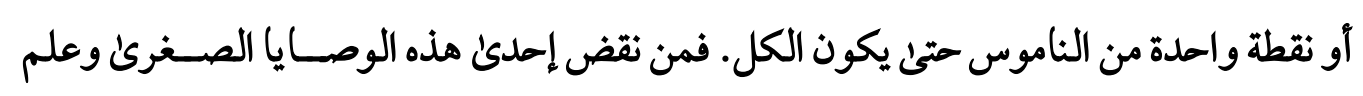

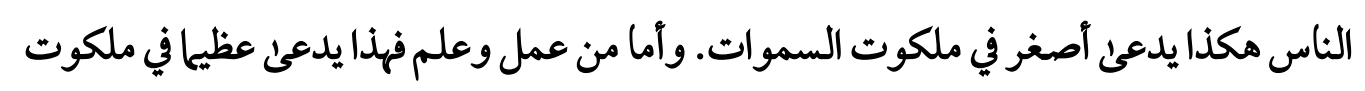
السموات.

والأناجيل التي بيد النصارئ لا تتضمن أي تشريع للمواريث فقد ظل المسيحيون يتوارثون بنظام

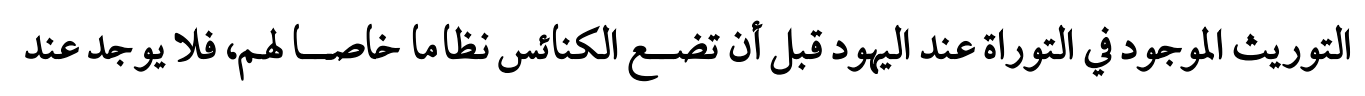

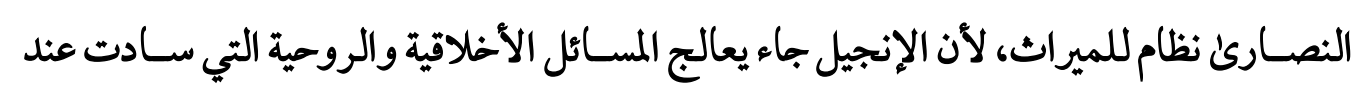

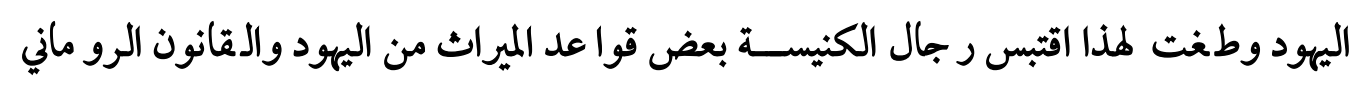

والشرائع الاخرى (') مبردئ

ميراث المراة يو الديانة المسيحية: سئل البابا شنودة الثالث عن موقف الكنيسة في تقسيم الميراث نظاما الحددا واسترشد بفقرات لوقا

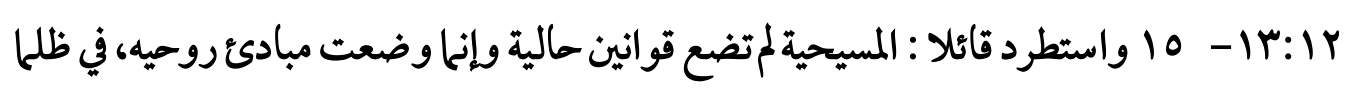

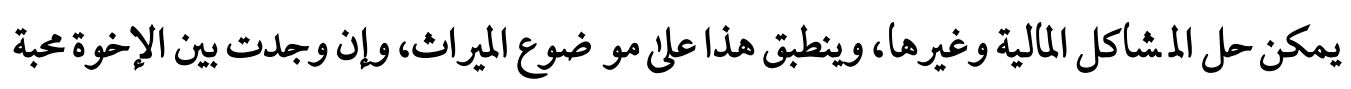

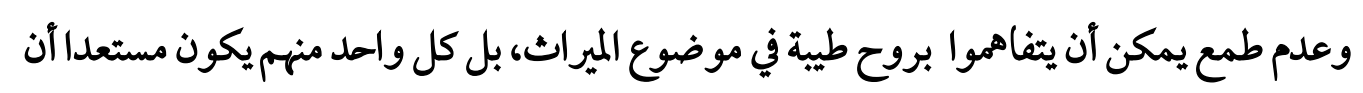
يترك نصيبه لأي واحد من أخواته أو إخوانه يرئ أنه محتاج آكثر منه (().

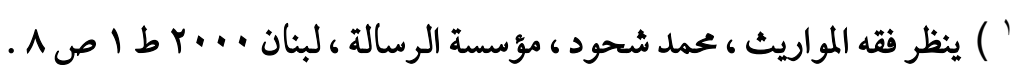

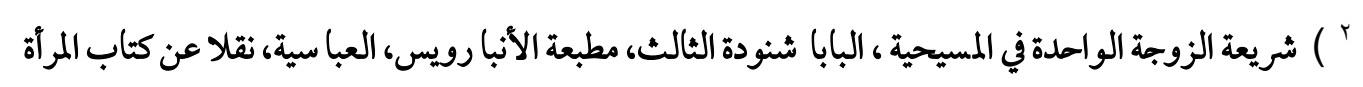

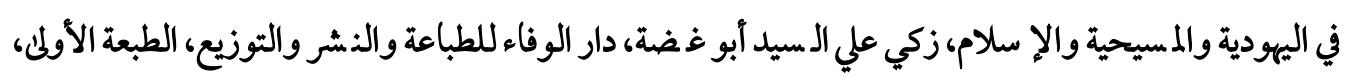
rir 
يقول صابر أحمد طه : إن نظام المواريث عند النصارئ و ضع بأيدي الأحبار والرهبان، فضلاعن أنه متضارب ومتناقض ولا يصلح للتطبيق العملي، فليس للنصارئ قانون مو حد يحتكمون إليه في

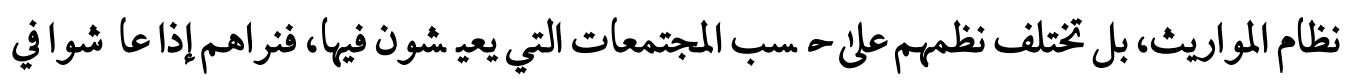
مجتمعات تساوي بين الرجل والمرأة في الميراث فعلوا مثل فعلهم.

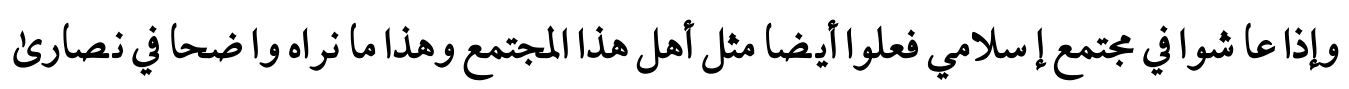

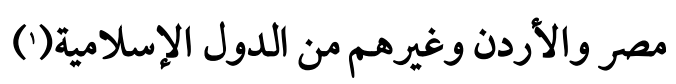
كحا أنه يوجد نوع من التصرف باسم القانون لتعديل أنصبة الورثة قبل وفاة أحد الو الدين، فمثلا إذا

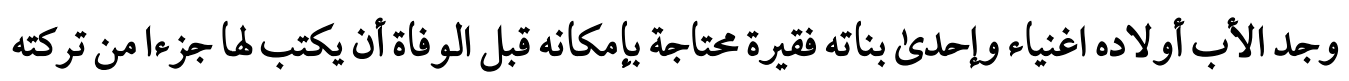
بطريقة شرعية .

\section{عدالة الاسلام بِ الميراث}

تجلت عدالة الاسلام في الميراث من جوانب عديدة اهمها ما يلي : 1 - لقد جاء الميراث مفصـلا في القران الكريم تفصـيلا علني غير عادة القران في ترك التفصـيل للسنة، جاء الميراث ومسائله بالتفصيل الدقيق، ولعل سورة النساء اوضحت معظم ما يتعلق بشان الميران الميراث، ويبدو ان الله اراد لمذه القضـية التي يتحقق فيها الثبوت وعدم التغير ان يكون فيها القول الفصل بجا لا يترك بجالا للاختلاف فيها وتلك عظمة التشريع. ب - قاعدة الإسلام الكبرئ في الميراث: الغرم بالغنم على هذه القاعدة قام قانون الميراث في الشريعة الوسط،

وعلئ هذه شرع الإسلام أن يرث الزوج الزوجة، وفق قاعدة (للذكر مثل حظ الانثين)(').

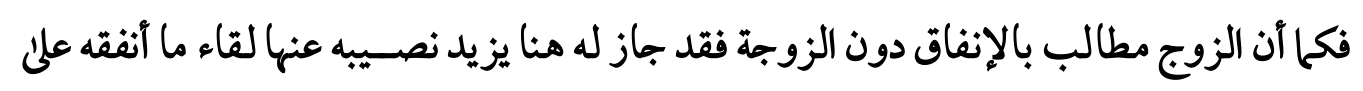
زوجته حال حياتها فتضاعف نصيبه عنها، وتلك من وسطية الإسلام في الميراث.

' ' ) نظام الأسرة في اليهودية والنصرانية والإسلام، صابر أمد طه، مرجع سابق، ص $19 V$

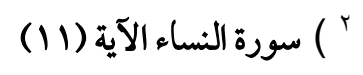


ولمذا شرع للو الدين نصـيبا في الميراث، تتسـاوئ الأم مع الأب فيه أحيانا، ويفوقها احيانا، وتفوقه الحيانا أخرىن، كل حسب ما يراه الشرع مصلحة لمجميع الأطراف ومن و سطية الإسلام في الميراث

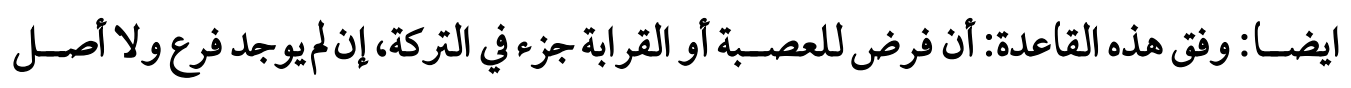
وارث، فليس من العدل آن يغرمهم الإسلام في دفع الدية، ولا يغنموا من الميراث شيئا إن لميحجبهم

ماجب.

ويظهر لنا هنا أن الو سطية حق وعدل وخيروهي مطلب شرعي اصيل ومقصدا سمى ومظهر هضاري

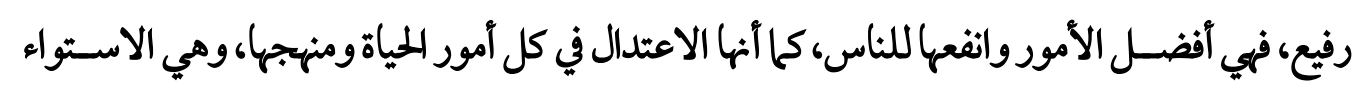

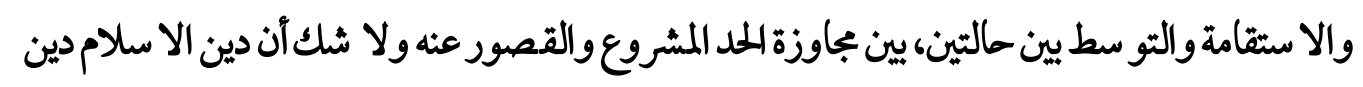

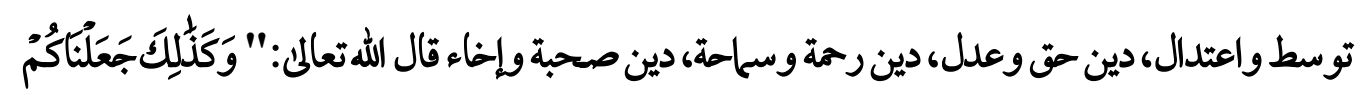

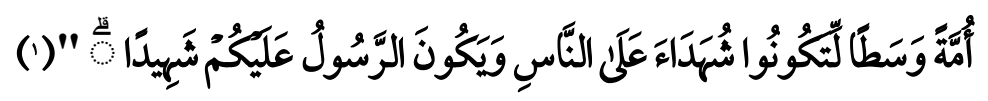
فالوسـطية منحة ربانية لهذه الأمة ومنهج الله القويم فيهم وتكريم منه سـبـحانه لتحقيق الأمن

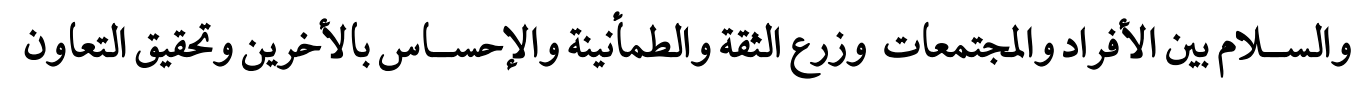
والتكافل بين الأغنياء والفقراء ومن تأمل المنهج الذي جاء به القرآن الكريم وتتبع أحكام الشريعة وما دعا إليه الحبيب - صـلناء الله عليه وسلم- في كل بجالات المياة، يجد الاعتدال واضحا، فقد كان عليه الصلاة والسلام ، وكانت

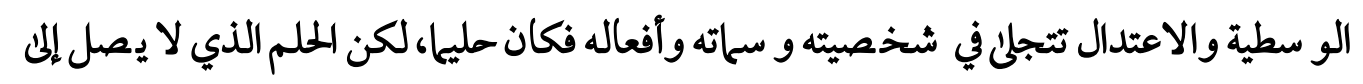

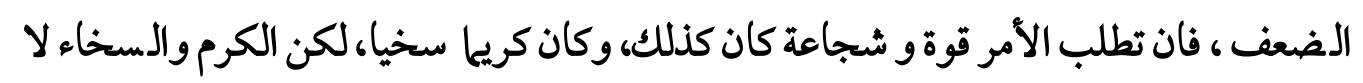

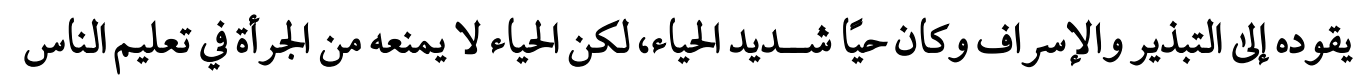

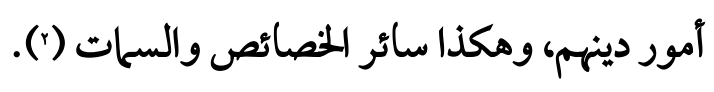

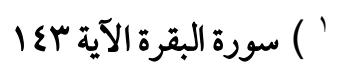

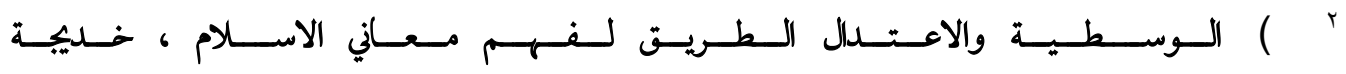

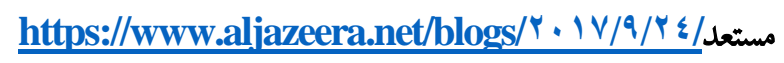


هل الذكر مفضل على الأنثى مطلقا يِّ الميراث؟ وهذا آمر يتداوله البعض علنى أل ستتهم، بعد آن قذف به الـشيطان في قلوبهم، فيقولون: لقد فضّل

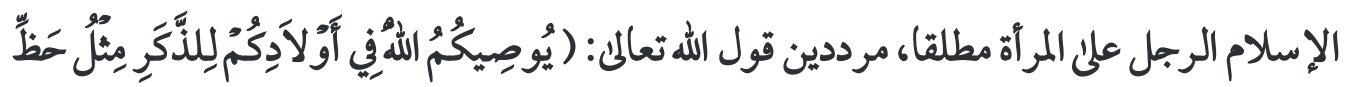

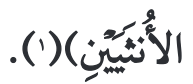

ويبدو أن أمثال هؤلاء تو هموا أن الإســلام فضّـــل الذكر على الأنثى مطلقا، و ما درى هؤلاء المتعجلون المشــككون أن توزيع التركة يختلف باختلاف وجود نوعية الذكر وكذلك نوعية الأنثى، ودرجة كل واحد منهلا من الميت قربا وبعدا، إضـافة إلى ما يتطلب من الوارث في حال الحياة، ومن

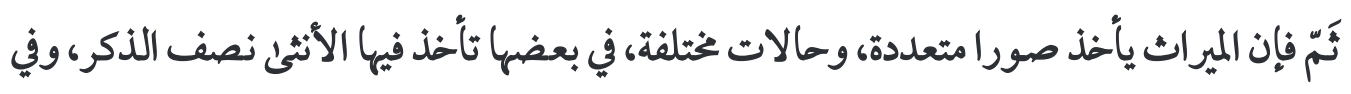

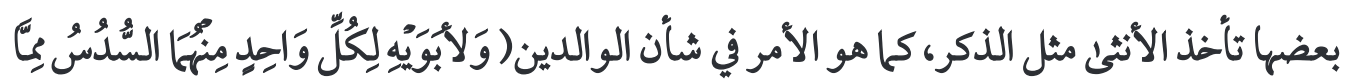

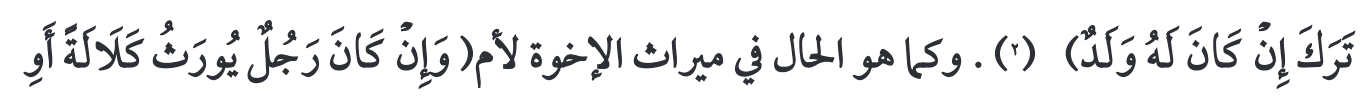

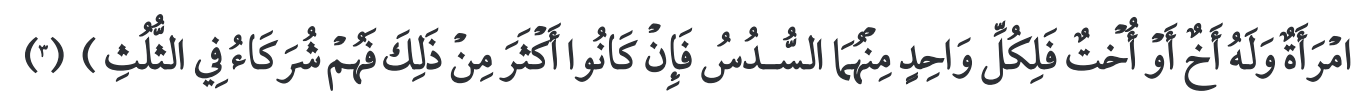
والحقيقة الدامغة والتي تطابق الواقع ان الاسلام في الميراث لميفضل الذكر على الانثلى على الدوام ن

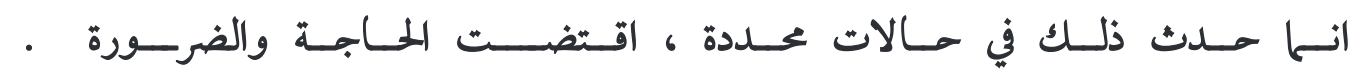
وهناك حالات أخرى ميز الإسلام فيها الأنثى على الذكر، وهناك حالات ترث فيها الأنثى ولا يرث الذكر شيئا، وهناك درا سة قام بها - صلاح سلطان - حول ميراث المرأة، وقدّم فيها آمثلة كثيرة، و ضع فيها المرآة مكان من يحاذيها من الرجال في قوة القرابة ودرجتها، فيقول: فإذا بالا ستقر اء يظهر ما يلي: هناك أربع حالات فقط ترث فيها المرأة نصف الرجل. وهناك حالات أضعاف ما سبق ترث فيها المرآة مثل الرجل تماما. وهناك حالات عشر ـآو تزيد ترث فيها المرأة أكثر من الرجل. وهناك

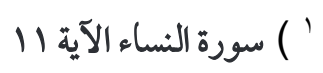

I r

r 


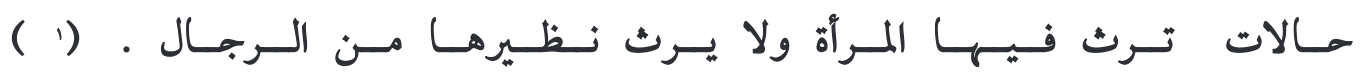

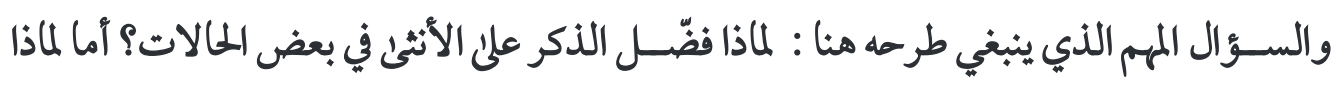

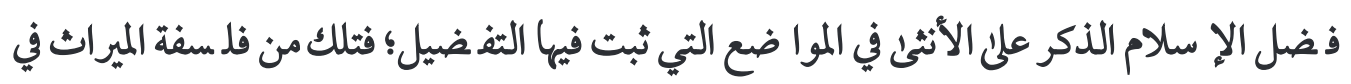

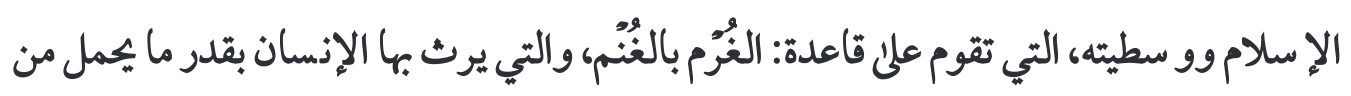
التكاليف، وما يقوم به من الواجبات تلك هي عدالة السـاء المطلقة، التي توازن دائما بين اللحقوق والواجبات، وقدا أ شار إلى هذا - مصطفى السباعي - في كتابه: (المرآة بين الفقه والقانون) فقال:

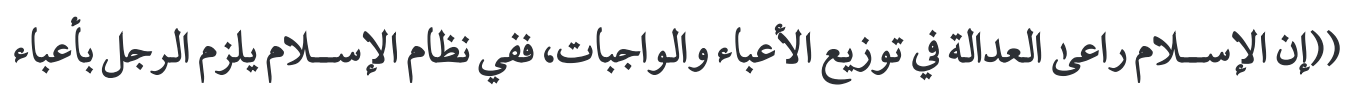

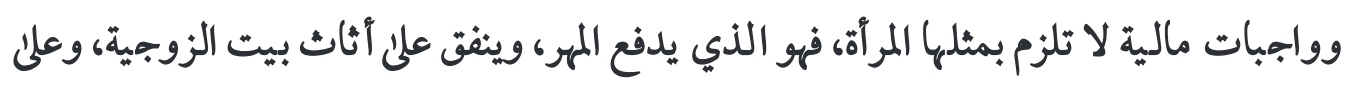

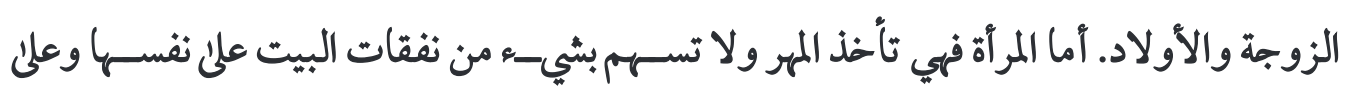

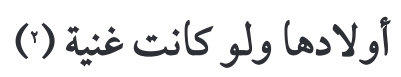
والمرآة كانت سببا في فرض الميراث: ومن روائع تشريع الميراث أن أول ما نزل من التشريع فيه كان

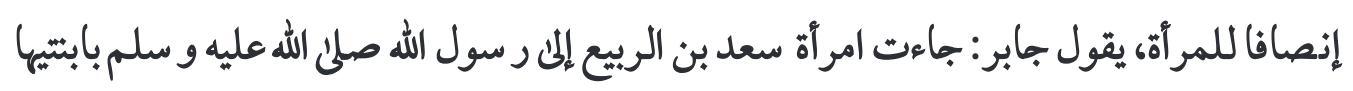

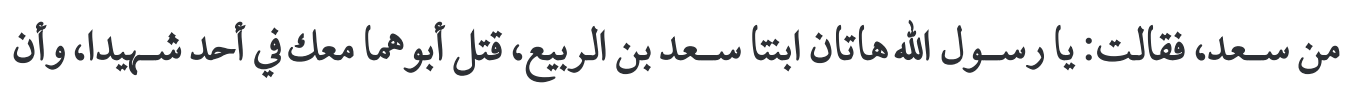

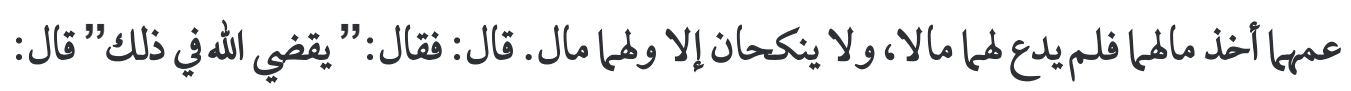

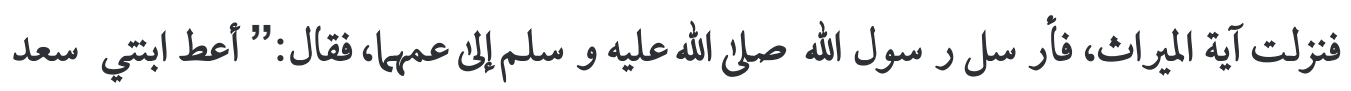

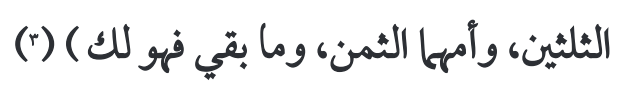
التدرج يخ تشريعات الميراث: كان من عادة العرب في الميراث الظلموالإجحاف في تق سيم التركة، ويناء عليه جاء الإ سلامليقوّم الظلم الين في توزيع التركة تدرييا، فأبقى الناس على ما هم عليه ستخى المجرة، ثم أبطل الإسـالام الإرث بالبني،

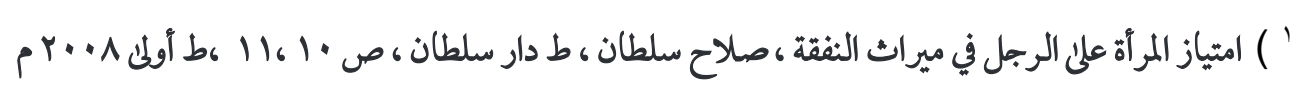

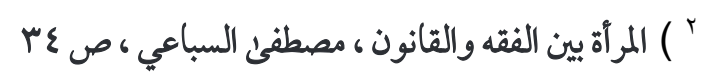

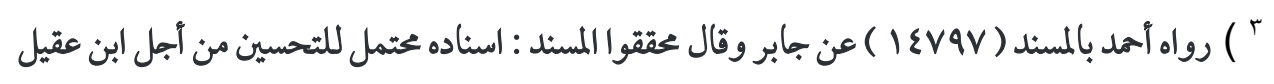


وآقر الإرث بلحلف والمعاقدة، والمؤاخاة والمجرة، من غير أن يحدد الشرـع المقادير والأنصـبة، ومن غير

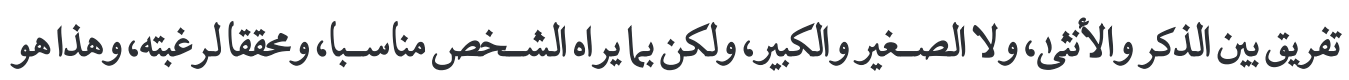

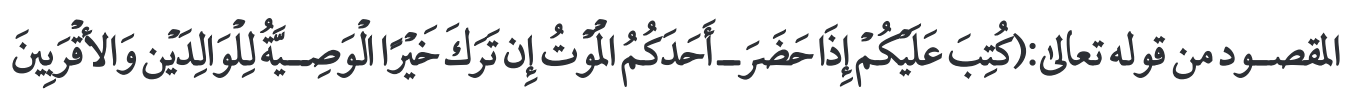

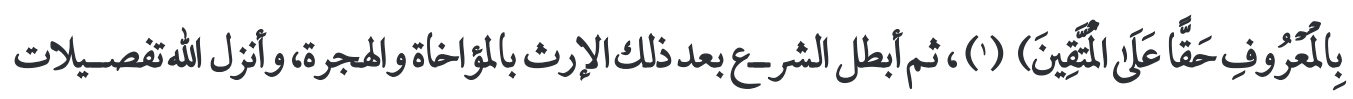

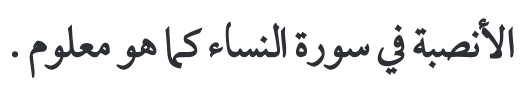
وقد جعل الاسلام أسباب الإرث ثلاثة هي: القرابة، والزوجية، والولاء. وتتجلنئ وسطية الإسلام

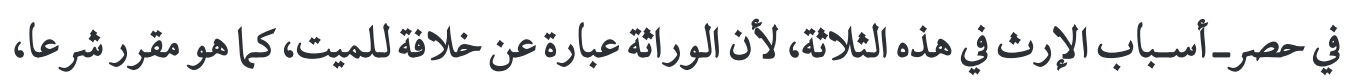
والملافة لا تكون إلا لمن يحتفظ في ذكره ومجده ونسـبه، ويكون ذكره الباقي في الفروع، أو لمن كان ان

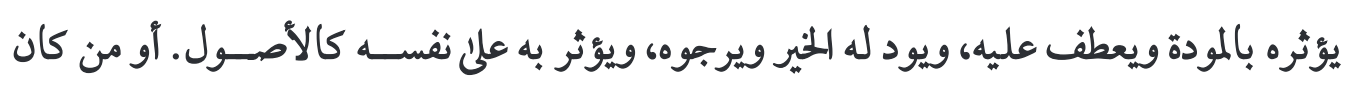

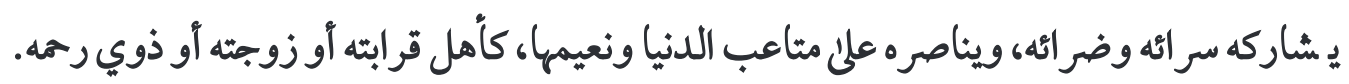

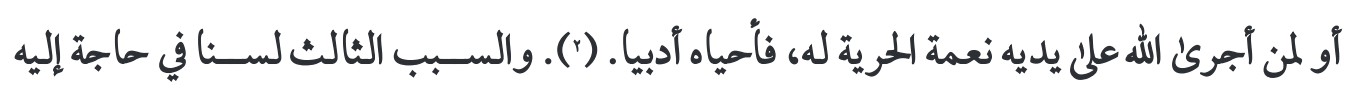

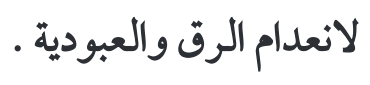

والميراث في شريعتنا نظام تعبدي إجباري: وهذا يعني آن هذا النظام لا ييوز للإنسـان تجاوزه أو

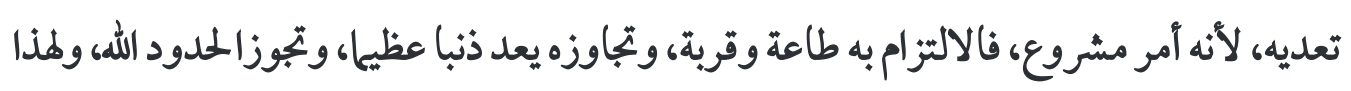

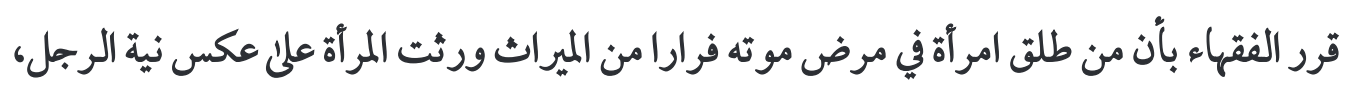

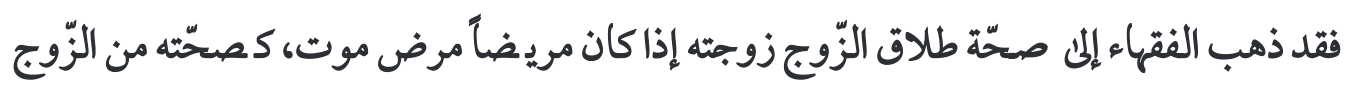

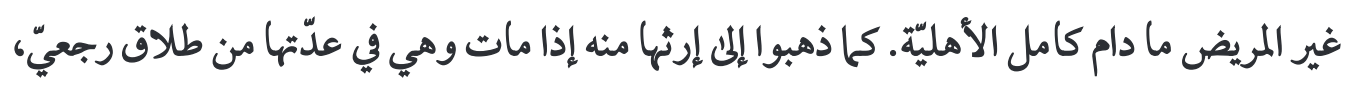

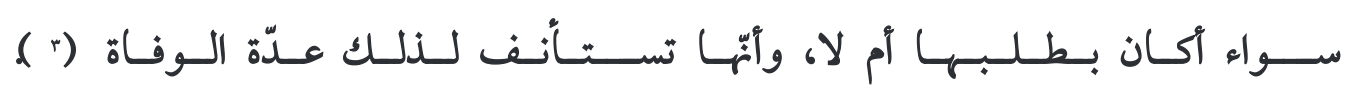

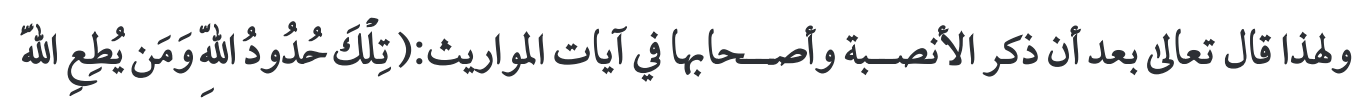

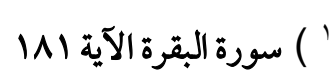

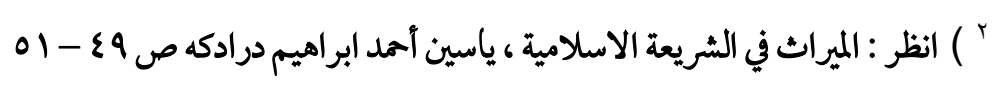

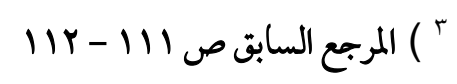




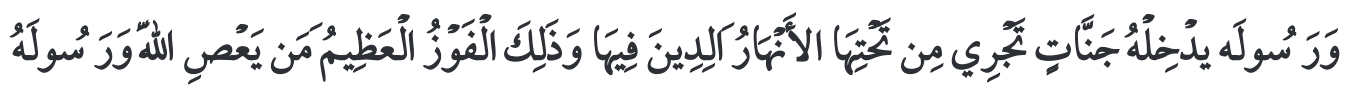

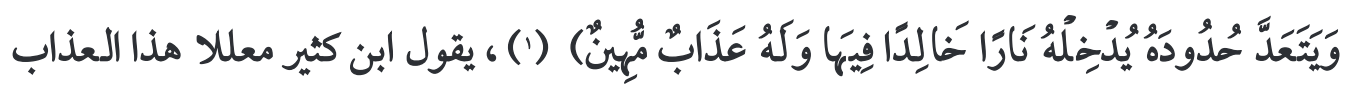

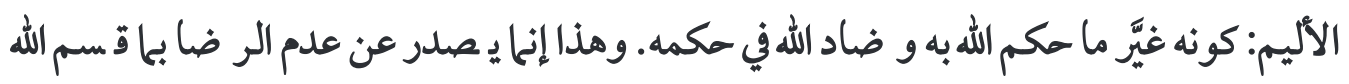

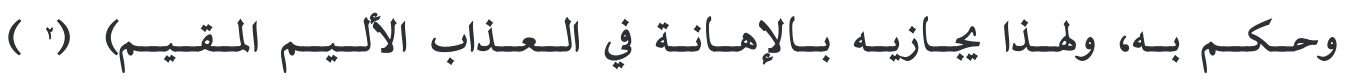

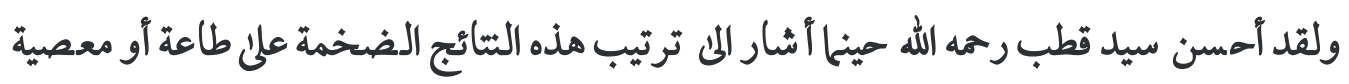

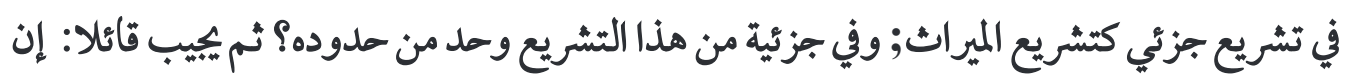

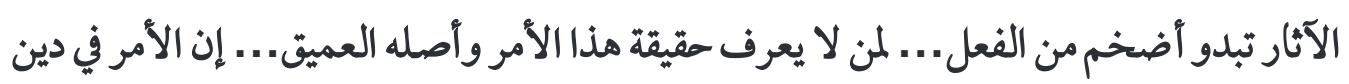

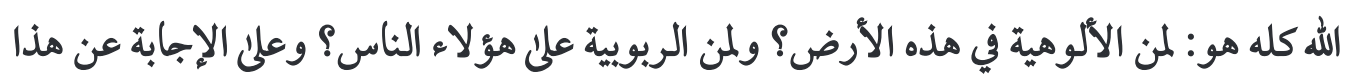

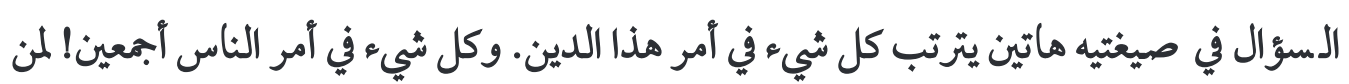

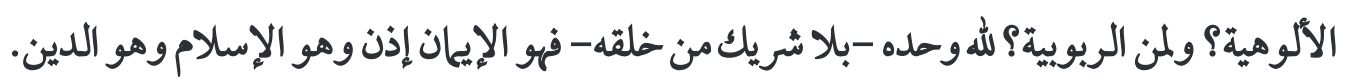

لشركاء من خلقه معه، أو لشركاء من خلقه دونه! فهو الشرك إذن أو الكفر المبين (r).

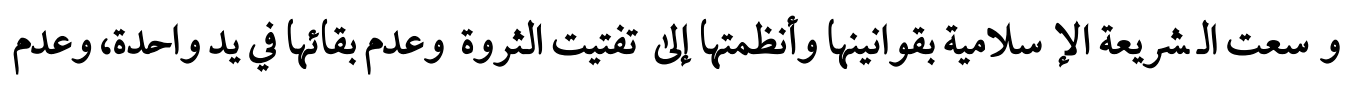
الاحتفاظ بها محصورة في يد بجموعة أو طائفة معينة، وهذا لا يدع بجالا لتضخم الثروة وتكدسها في أيد قليلة ثابتة - كما يقع في الأنظمة التي تجعل الميراث لأكبر ولد ذكر - أو تحصره في طبقات قليلةوهو في هذه الناحية أداة متجددة الفاعلية في إعادة التنظيم الاقتصـادي في الجماعة، ورده إلى الاعتدال، دون تدخل مباشر من السـلطات. هذا التدخل الذي لا تسـتريح إليه النفس البشر-ية بطبيعة ما ركب فيها من الحرص والشح، فأما هذا الثفتيت المستمر والتوزيع المتجدد، فيتم والنفس

$$
\begin{aligned}
& \text { ' ) سورة النساء الآية با، ع| }
\end{aligned}
$$

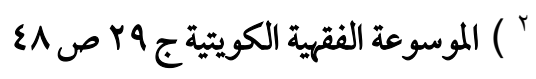

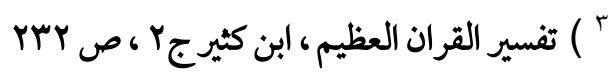


به راضية، لأنه يتحاشئ مع فطرته وحرصها وشحها ، وهذا هو الفارق الأصيل بين تشريع اللهلذه

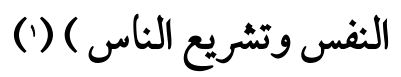
ويمكن هنا الجزم بأن الشريعة الإسلامية قد اعتمدت على الوسطية المؤدية إلى تحقيق العدل ، الذي يتنا سب مع حاجات الناس ويحقق العدالة بينهم، وفق حاجات الشخص ومدئ صلة القربلى بينه ويين الميت ، وكيف لا يكون ذلك وهو حكم رب العزة والجلال مصداقا لقوله تعالى : (ومن أحسن من اللهحكا لقوم يوقنون ) (') وقد تميز علن غيره من الانظمة سواء الوضعية في الجاملية الاولم قبل الا سلام ، او الجاملية المعاصرة ، وكذلك الديانات التي سبقته . فجاء نظاما محكما بعيدا عن الموئ والميل الشخصي وتقديم المصلحة الخاصة ، مما يحقق الانسجام والتناغم بين الافراد والمجاعات . وهنا يتضـح جليا آن نظام المواريث في الإسـلام قد انسـجم مع الثوجيه الرباني في قول اللهتعالم: (وكذلك جعلناكم أمة وسطالتكونوا شهداء على الناس ويكون الرسول عليكم شهيدا) (·) فالوسطية متحققة في نظام الميراث الإسلامي كما هي متحققة في شتن مناحي الشريعة وأحكامها العادلة.

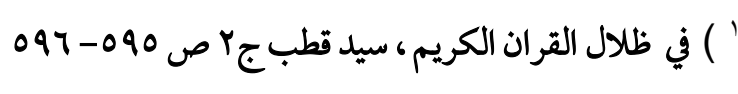

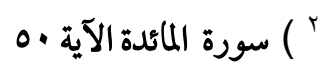

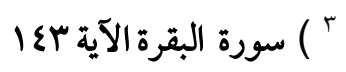




\section{الثـــات}

في ختام هذه الدراسة خلص الباحث الما النتائج التالية :

(1) الشريعة الإسلامية وضعت نظام المواريث على أحسن النظم المالية وأحكمها وآعدهل) (Y) الإ سلام وقف موقفاو سطا بين الا شتراكية الشيوعية وبين الرأ سلالية والمذاهب التي تقوم بحرية التملك . (r) علم المواريث وعلم الفرائ مسميان لأمر واحد وهو ما يتركه المتوفن من آموال . (ع) احترم الإسلام الملكية الفردية وضمن أن يتتقل الملال من الشخص المى ورثثه الاقربون بعد وفاته . (0) فصل القران الكريم أحكام المواريث بخلاف باقي الأحكام الشرعية فقد وردت بجملة وذلك

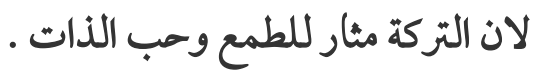
(7 ) أن علم) الإسلام قد أهتموا بعلم المواريث سلفا وخلفا . (V) آن نظام المواريث في الإسلام قد امتاز بمميزات عديدة ميزته عن غيره من الأنظمة الأخرى'. (1) آن نظام المواريث في الإسلام حفظ حقوق المستضعفين من النساء والاطفال . (9) أن الأنظمة الأخرى في الميراث سـواء عند اليهود أو المسـيحية أو الجاهلية قد جانبت الصـواب كثيرا ومارست الظلم بحق بعض الورثة . ( ( ) آن الرجل ليس مفضلا في الميراث دائم) على المرآة ، فهناك حالات عديدة تفضل المرآة الرجل

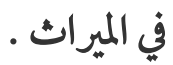


$-1 \cdot 1 .=$ 